\title{
Drought-Sensitive Aquifer Settings in Southeastern Pennsylvania
}

by Tammy M. Zimmerman and Dennis W. Risser

In cooperation with the

Pennsylvania Department of Conservation and Natural Resources,

Bureau of Topographic and Geologic Survey

Scientific Investigations Report 2005-5169

U.S. Department of the Interior

U.S. Geological Survey 


\title{
U.S. Department of the Interior Gale A. Norton, Secretary
}

\author{
U.S. Geological Survey \\ P. Patrick Leahy, Acting Director
}

U.S. Geological Survey, Reston, Virginia: 2005 For sale by U.S. Geological Survey, Information Services
Box 25286, Denver Federal Center
Denver, CO 80225
For more information about the USGS and its products:
Telephone: 1-888-ASK-USGS
World Wide Web: http://www. usgs.gov/
Any use of trade, product, or firm names in this publication is for descriptive purposes only and does not imply
endorsement by the U.S. Government.
Although this report is in the public domain, permission must be secured from the individual copyright owners to repro-
duce any copyrighted materials contained within this report.

Suggested citation:

Zimmerman, T.M., and Risser, D.W., 2005, Drought-sensitive aquifer settings in southeastern Pennsylvania: U.S. Geological Survey Scientific Investigations Report 2005-5169, 21 p. 


\section{Contents}

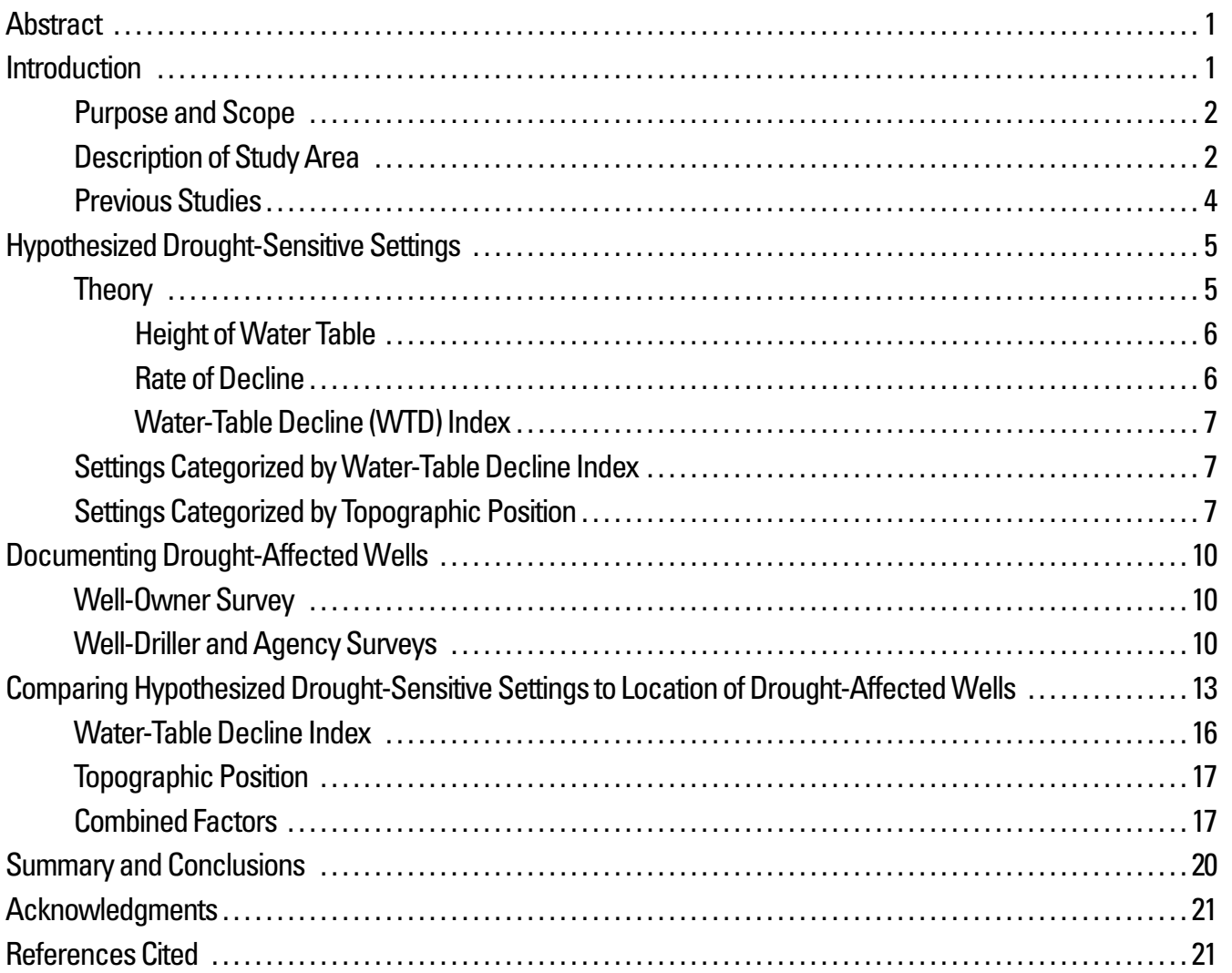

\section{Figures}

1. Map showing study area as defined by the Piedmont and New England Physiographic Provinces and South Mountain Section of the Ridge and Valley Physiographic Province of

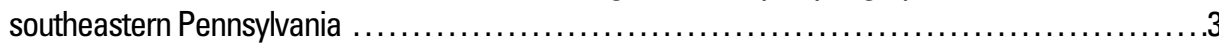

2. Sketch showing idealized strip aquifer of width (2a) and infinite length, with constant recharge $(W)$, showing height of water table $\left(h_{0}\right)$ above draining stream.

3. Graph showing simulated water-level declines in wells at upland, mid-slope, and nearstream locations for the idealized aquifer shown in figure 2

4. Map showing location of drought-affected wells in southeastern Pennsylvania during 1998-2002 as determined from results of well-owner, well-driller, and agency surveys

5. Graphs showing drought-affected wells reported by Chester and Montgomery County Health Departments and cumulative departure from normal precipitation, 1998-2002.

6. Maps showing density of drought-affected wells during the 1999 and 2002 droughts in (A) Chester County and (B) Montgomery County, Pennsylvania.

7. Graph showing relation between water-table decline index (low, moderate, high) and incidence of drought-affected wells reported by Chester and Montgomery County Health Departments, southeastern Pennsylvania, during the 1999 and 2002 droughts and as a percentage of Water Well Inventory (WWI) wells. 
8. Graph showing relation between topographic position (valley, slope, upland) and incidence of drought-affected wells reported by Chester and Montgomery County Health Departments, southeastern Pennsylvania, during the 1999 and 2002 droughts and as a

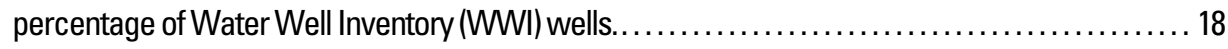

9. Map showing drought-sensitive settings in southeastern Pennsylvania determined by water-table decline index of geologic units and topographic position

\section{Tables}

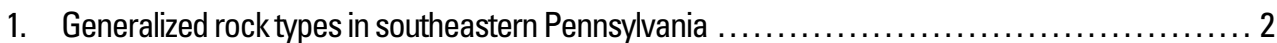

2. Households with private wells in the study area, southeastern Pennsylvania, $1990 \ldots \ldots \ldots \ldots \ldots 4$

3. Streamflow-recession index for three streams in basins underlain by different

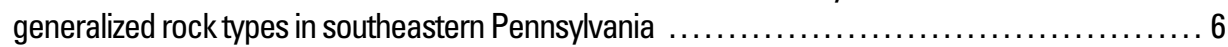

4. Categorization of aquifers in southeastern Pennsylvania by water-table decline index .......... 8

5. Results from the 35 responses to the well-owner survey showing characteristics of domestic-supply wells in southeastern Pennsylvania affected by drought in $2002 \ldots \ldots \ldots \ldots \ldots 12$

6. Dry wells in each aquifer in Chester and Montgomery Counties, Pennsylvania, expressed per 100 square miles and as percentage of Water Well Inventory wells............. 16

7. Comparison of drought-affected wells (1999 and 2002 droughts) in Chester and Montgomery Counties, Pennsylvania, in nine settings defined as the intersection of water-table decline index and topographic position .

\section{Conversion Factors}

\begin{tabular}{|c|c|c|}
\hline Multiply & By & To obtain \\
\hline \multicolumn{3}{|c|}{ Length } \\
\hline foot (ft) & 0.3048 & meter $(\mathrm{m})$ \\
\hline \multicolumn{3}{|c|}{ Area } \\
\hline square mile $\left(\mathrm{mi}^{2}\right)$ & 2.590 & square kilometer $\left(\mathrm{km}^{2}\right)$ \\
\hline \multicolumn{3}{|c|}{ Flow rate } \\
\hline inch per year (in/yr) & 25.4 & millimeter per year $(\mathrm{mm} / \mathrm{yr})$ \\
\hline \multicolumn{3}{|c|}{ Transmissivity* } \\
\hline foot squared per day $\left(\mathrm{ft}^{2} / \mathrm{d}\right)$ & 0.09290 & meter squared per day $\left(\mathrm{m}^{2} / \mathrm{d}\right)$ \\
\hline
\end{tabular}

*Transmissivity: The standard unit for transmissivity is cubic foot per day per square foot times foot of aquifer thickness $\left[\left(\mathrm{ft}^{3} / \mathrm{d}\right) / \mathrm{ft}^{2}\right] \mathrm{ft}$. In this report, the mathematically reduced form, foot squared per day $\left(\mathrm{ft}^{2} / \mathrm{d}\right)$, is used for convenience. 


\title{
Drought-Sensitive Aquifer Settings in Southeastern Pennsylvania
}

\author{
by Tammy M. Zimmerman and Dennis W. Risser
}

\section{Abstract}

This report describes the results of a study conducted by the U.S. Geological Survey, in cooperation with the Pennsylvania Department of Conservation and Natural Resources, Bureau of Topographic and Geologic Survey, to determine droughtsensitive aquifer settings in southeastern Pennsylvania.

Because all or parts of southeastern Pennsylvania have been in drought-warning or drought-emergency status during 6 of the past 10 years from 1994 through 2004, this information should aid well owners, drillers, and water-resource managers in guiding appropriate well construction and sustainable use of Pennsylvania's water resources.

"Drought-sensitive" aquifer settings are defined for this study as areas unable to supply adequate quantities of water to wells during drought. Using information from previous investigations and a knowledge of the hydrogeology and topography of the study area, drought-sensitive aquifer settings in southeastern Pennsylvania were hypothesized as being associated with two factors - a water-table decline (WTD) index and topographic setting. The WTD index is an estimate of the theoretical water-table decline at the ground-water divide for a hypothetical aquifer with idealized geometry. The index shows the magnitude of ground-water decline after cessation of recharge is a function of (1) distance from stream to divide, (2) ground-water recharge rate, (3) transmissivity, (4) specific yield, and (5) duration of the drought. WTD indices were developed for 39 aquifers that were subsequently grouped into categories of high, moderate, and low WTD index.

Drought-sensitive settings determined from the hypothesized factors were compared to locations of wells known to have been affected (gone dry, replaced, or deepened) during recent droughts. Information collected from well owners, drillers, and public agencies identified 2,016 wells affected by drought during 1998-2002. Most of the available data on the location of drought-affected wells in the study area were from Chester and Montgomery Counties because those counties have well-construction regulations that identify wells that failed during drought. The locations of drought-affected wells in Chester and Montgomery Counties indicated the most highly sensitive settings are uplands and slopes in aquifers with high WTD index and uplands in aquifers with moderate WTD index. The least sensitive settings are in aquifers with low WTD index, in valleys, or on slopes. A map was developed showing the relative drought sensitivity (low, moderate, and high) of aquifers in southeastern Pennsylvania.

Study results were limited by the inability to obtain much information about the location of drought-affected wells, with the exception of Montgomery and Chester Counties. Also, the construction characteristics (particularly depth) of droughtaffected wells generally were not available. Well depth could be used to distinguish between problems caused by shallow well depth (generally less than $100 \mathrm{ft}$ ) and those caused by deficiency of the aquifer to supply water. With the exception of owner-derived information from a public survey on droughtaffected wells (35 wells), depth data were not obtained. Data from the 35 drought-affected wells indicated most were drilled (not dug) and were completed to depths greater than 100 feet. This finding indicates that the affects of recent droughts in southeastern Pennsylvania were not restricted to shallow dug wells, but also affected deeper drilled wells.

\section{Introduction}

All or parts of southeastern Pennsylvania have been in drought-warning or drought-emergency status during 6 of the past 10 years from 1994 through 2004 (Pennsylvania Department of Environmental Protection, 2004). In response to the precipitation deficits during these droughts, ground-water levels throughout most of southeastern Pennsylvania fell below seasonal average levels and, in some cases, all-time historic low levels. The low ground-water levels have caused hundreds of domestic-supply wells to go dry or become unusable because of decreased yield (Kyle Schmeck, Montgomery County Health Department, written commun., 2002; Benjamin Aller, Chester County Health Department, written commun., 2002).

"Drought-sensitive" aquifer settings are defined for this study as areas unable to supply adequate quantities of water to wells during dry periods. This is a loose definition aimed to broadly identify areas that might be most problematic for well owners during droughts. Whether or not a well "goes dry" dur- 


\section{Drought Sensitive Aquifer Settings in Southeastern Pennsylvania}

ing a drought depends on the severity of drought, the inherent sensitivity of the aquifer setting to reduced recharge, and the characteristics of the well-predominantly its depth. During droughts, anecdotal and media reports frequently document the occurrence of wells going dry but whether they are related to a site-specific well-construction problem or an insufficient supply of water within the larger aquifer setting is usually not clear.

Information about the location and extent of drought-sensitive aquifer settings in southeastern Pennsylvania is needed to identify areas where ground-water shortages may occur during times of drought. Such information would assist well owners to obtain wells of adequate depth, allow developers to more accurately plan for adequate water supplies, and help planners and water-resources managers guide the sustainable use of Pennsylvania's water resources. In 2002, the U.S. Geological Survey (USGS), in cooperation with the Pennsylvania Department of Conservation and Natural Resources, Bureau of Topographic and Geologic Survey (PaGS), began a study to identify droughtsensitive aquifer settings in southeastern Pennsylvania where ground-water shortages may result during drought.

\section{Purpose and Scope}

This report presents and tests a hypothesis about the conditions creating drought-sensitive aquifer settings in southeastern Pennsylvania. Probable drought-sensitive aquifer settings are identified on the basis of a water-table decline (WTD) index and topography. The drought-sensitive aquifer settings are compared to locations of drought-affected wells in Chester and Montgomery Counties identified by the County Health Departments during the two most recent droughts (December 1998 through September 1999 and November 2001 through November 2002) to confirm or refute the hypothesis that wells located in aquifers categorized as drought sensitive are problematic during drought. Overall, drought sensitivities are defined on the basis of hypothesized factors that may be useful for identifying the spatial distribution of drought-affected wells in southeastern Pennsylvania. The scope of the report is limited to evaluating the effect of drought on wells; the effect on base flow to streams is not discussed.

\section{Description of Study Area}

The study area is the Piedmont and New England Physiographic Provinces and South Mountain Section of the Ridge and Valley Physiographic Province of southeastern Pennsylvania (fig. 1). The area is approximately $5,100 \mathrm{mi}^{2}$ and spans all or parts of Adams, Berks, Bucks, Chester, Cumberland, Dauphin, Delaware, Franklin, Lancaster, Lebanon, Lehigh, Montgomery, Northampton, and York Counties.

The physiography of the study area is diverse. Topography varies from the pronounced ridges and deep valleys of the South Mountain Section of the Ridge and Valley Physiographic Province to the broad valleys separated by low hills of the Piedmont Lowland Section of the Piedmont Physiographic Province (Sevon, 2000). Geology varies from igneous and metamorphic rocks of Precambrian age that have undergone multiple periods of intense deformation to sedimentary rocks of Triassic age that have undergone relatively little deformation compared to the igneous rocks.

Characteristics of aquifers within the study area also are diverse, but aquifers generally can be categorized according to generalized rock type (table 1). Ground water is present and moves in crystalline (igneous and metamorphic), siliciclastic (sandstone and shale), and carbonate (limestone and dolomite) aquifers primarily within fracture space in the rock, although in some valley settings the saturated regolith can store and transmit water. The frequency of water-bearing fractures tends to diminish with depth, so ground-water-flow paths are local and shallow-generally less than about $400 \mathrm{ft}$ deep (Low and others, 2002). In the Gettysburg-Newark Lowland Section of the Piedmont Physiographic Province, water-producing fractures sometimes are encountered at depths as great as $600 \mathrm{ft}$. Deep water-producing zones are a characteristic that would make these aquifers inherently less susceptible to dewatering of water-bearing fractures during drought.

Table 1. Generalized rock types in southeastern Pennsylvania.

\begin{tabular}{llc}
\hline Generalized rock type & $\begin{array}{c}\text { Specific rock types within each generalized rock- } \\
\text { type category }\end{array}$ & Principal physiographic setting \\
\hline Crystalline & $\begin{array}{c}\text { Igneous and metamorphic rocks predominate. } \\
\text { Major lithologies are schist, gneiss, diabase, } \\
\text { quartzite, phyllite, and metavolcanics. }\end{array}$ & $\begin{array}{c}\text { South Mountain Section of Ridge and Valley Prov- } \\
\text { ince, Reading Prong Section of New England } \\
\text { Province, and Upland Section of Piedmont Prov- } \\
\text { ince, Gettysburg-Newark Lowland Section of } \\
\text { Piedmont Province (diabase only) }\end{array}$ \\
& Sandstone, siltstone, shale, and conglomerate. & $\begin{array}{c}\text { Gettysburg-Newark Lowland Section of Piedmont } \\
\text { Province }\end{array}$ \\
Phylitic shale. & Lowland Section of Piedmont Province \\
Larbonate & Limestone and dolomite with some interbedded & Lowland Section of Piedmont Province \\
\hline
\end{tabular}


PHYSIOGRAPHIC PROVINCE AND SECTION PIEDMONT PHYSIOGRAPHIC PROVINCE Gettysburg-Newark Lowland section

Piedmont Lowland section

Piedmont Upland section

NEW ENGLAND PHYSIOGRAPHIC PROVINCE Reading Prong section RIDGE AND VALLEY PHYSIOGRAPHIC PROVINCE

South Mountain section

$$
\left.\left.\right|_{0} ^{0}\right|_{15 \text { KILOMETERS }} ^{1} \underbrace{15}_{15} \text { MILES }
$$

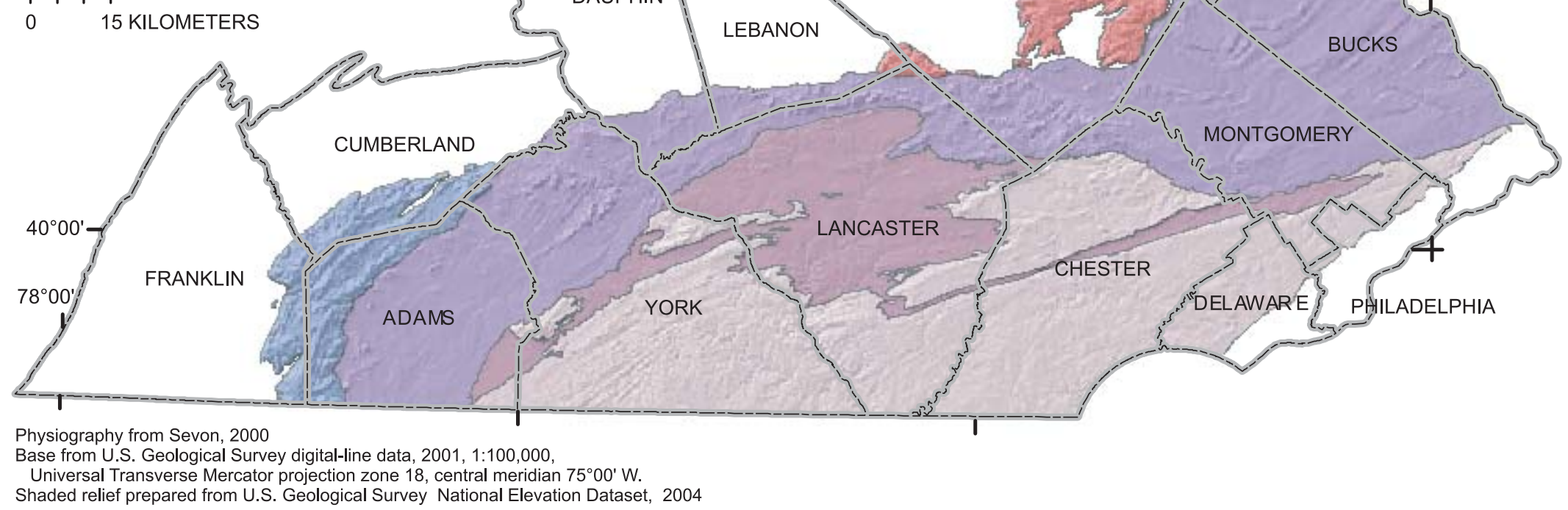

Figure 1. Study area as defined by the Piedmont and New England Physiographic Provinces and South Mountain Section of the Ridge and Valley Physiographic Province of southeastern Pennsylvania. 


\section{Drought Sensitive Aquifer Settings in Southeastern Pennsylvania}

The study area contains a large rural population that depends on ground water from private on-lot wells as a daily source of drinking water and a source of water for livestock. These private on-lot wells are more vulnerable to drought conditions because they typically are shallower and yield less water than wells drilled for public-supply, commercial, or industrial uses. About 385,000 households in the study area rely on ground water from private on-lot wells for daily water supply (U.S. Bureau of the Census, 1992). Southeastern Pennsylvania has a greater density of private on-lot wells compared to Pennsylvania as a whole (Fleeger, 1999). Reliance on private wells is particularly great for residents of Adams County, where 56 percent of households have private wells (table 2 ).

\section{Previous Studies}

The hydrogeology of southeastern Pennsylvania has been extensively studied and is documented in numerous reports. Most of these studies provided information about ground-water availability and well yields, but few specifically characterized drought-sensitive aquifer settings in southeastern Pennsylvania. Using the information from these previous studies, Low and others (2002) described the hydrogeology of the study area and analyzed well data from over 12,000 wells in the USGS Ground-Water Site Inventory (GWSI) database and the PaGS Water Well Inventory (WWI) database.

The hypothetical effects of drought on the ground-water resources in parts of southeastern Pennsylvania were estimated in past studies by the use of ground-water-flow models. Gerhart and Lazorchick (1984) simulated effects of a winter-spring drought in parts of Berks and Lancaster Counties and showed that ground-water levels declined most in the Triassic-age sedimentary rocks and least in the carbonate rocks. In a related study, Gerhart and Lazorchick (1988) simulated ground-water declines throughout the lower Susquehanna River Basin in response to basinwide ground-water withdrawals. Model-simulation results from the two studies can be viewed as showing the effect of drought if simulated ground-water withdrawals are interpreted as a reduction in recharge instead of an increase in pumping. In Chester County, Sloto (2004) simulated the effects of drought and ground-water withdrawals in the French Creek Basin, with an emphasis on estimating the reduction of base flow to streams. Ground-water declines at various locations within the watershed were shown for a simulated drought of 90 days.

Table 2. Households with private wells in the study area, southeastern Pennsylvania, 1990.

[From U.S. Bureau of Census, 1992]

\begin{tabular}{lcccc}
\hline \multicolumn{1}{c}{$\begin{array}{l}\text { County } \\
\text { (Fig. 1) }\end{array}$} & $\begin{array}{c}\text { Number of } \\
\text { households }\end{array}$ & $\begin{array}{c}\text { Number of } \\
\text { households with } \\
\text { private wells }\end{array}$ & $\begin{array}{c}\text { Total estimated } \\
\text { water usage } \\
\text { (gallons per day) } \\
\text { in households } \\
\text { with private wells }\end{array}$ & $\begin{array}{c}\text { Percentage of } \\
\text { households } \\
\text { with private } \\
\text { wells }\end{array}$ \\
\hline Adams $^{2}$ & 28,066 & 15,655 & $3,804,000$ & 56 \\
Berks & 127,849 & 38,847 & $9,440,000$ & 30 \\
Bucks & 190,312 & 45,507 & $11,058,000$ & 24 \\
Chester & 133,592 & 49,316 & $11,984,000$ & 37 \\
Cumberland & 73,506 & 19,587 & $4,760,000$ & 27 \\
Dauphin & 95,123 & 21,655 & $5,262,000$ & 23 \\
Delaware & 201,618 & 6,757 & $1,642,000$ & 3 \\
Franklin & 45,642 & 14,455 & $3,513,000$ & 32 \\
Lancaster & 151,352 & 50,966 & $12,385,000$ & 34 \\
Lebanon & 42,7098 & 13,034 & $3,167,000$ & 31 \\
Lehigh & 112,552 & 17,465 & $4,244,000$ & 16 \\
Montgomery & 254,596 & 30,716 & $7,464,000$ & 12 \\
Northampton & 90,619 & 17,456 & $4,242,000$ & 19 \\
York ${ }^{2}$ & 128,764 & 43,441 & $10,556,000$ & 34 \\
\multicolumn{1}{c}{ Total } & $1,676,299$ & 384,857 & $93,520,000$ & 23 \\
\hline
\end{tabular}

${ }^{1}$ Based on an average of 243 gallons of water per day per average household of four persons.

${ }^{2}$ The county is entirely within the study area. All other counties are only partially in the study area. 
A recent study was conducted as a direct result of the drought of 1998-99 when more than 20 private wells went dry in the Borough of Carroll Valley in Adams County. Low and Conger (2002) used data from 369 wells throughout an area of about $5 \mathrm{mi}^{2}$ to show the crystalline-rock aquifers-metabasalt, metarhyolite, and greenstone schist-yielded only small amounts of water to the wells. The low yields, coupled with shallow water-bearing zones, probable poor connection to ground-water storage in the regolith, and seasonal water-level declines of as much as $40 \mathrm{ft}$, illustrated the susceptibility of these aquifers to drought.

\section{Hypothesized Drought-Sensitive Settings}

Drought-sensitive aquifer settings are defined in this study as those that fail to supply adequate quantities of water to wells during dry periods (droughts). Assuming well-construction characteristics are not variable, the most problems with water wells usually occur during drought in areas where the decline in water-table altitude is greatest or where the water table falls below major water-producing fractures. Theoretically, the magnitude of water-table decline during drought should be related to the initial height of the water table and the rate at which the water table declines when recharge ceases.

\section{Theory}

Consider the case of an idealized strip aquifer of infinite length receiving uniform recharge as shown in figure 2 . In this case, the aquifer transmissivity and stream stage are assumed to be constant. The distance from the stream to the ground-water divide is $a$, and the steady-state height of the water table above the stream is $h_{o}$ for any distance $x$ from the stream.

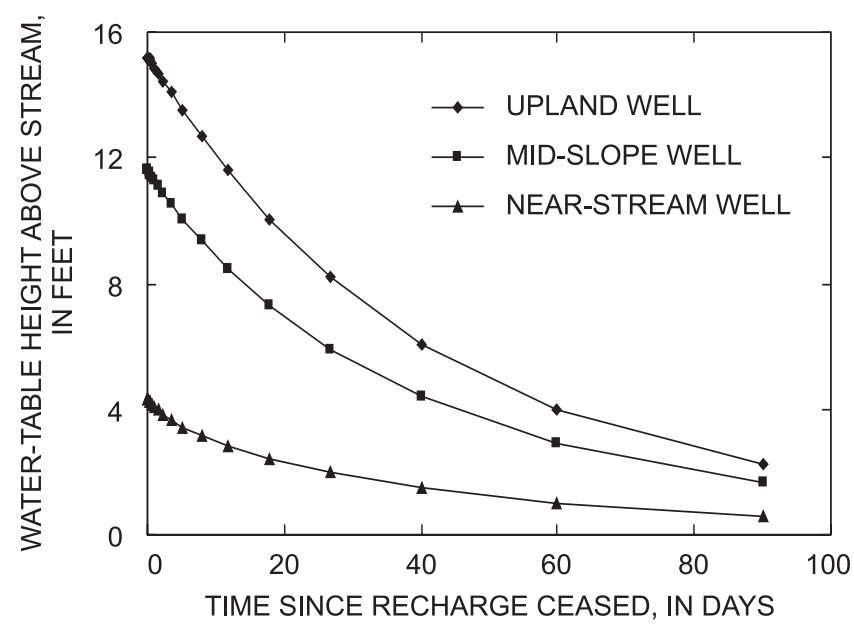

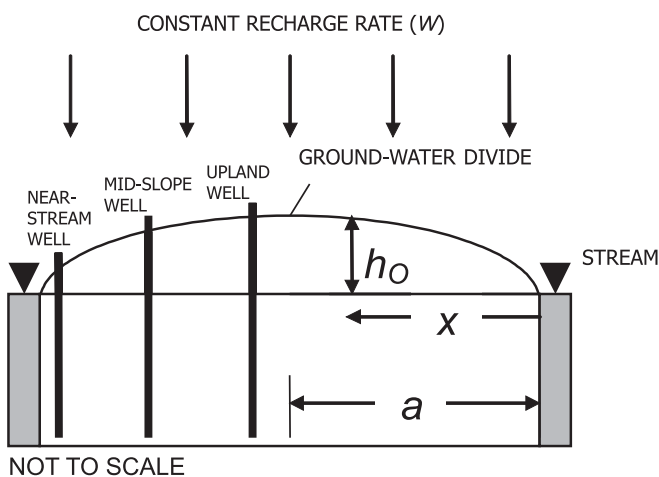

Figure 2. Idealized strip aquifer of width (2a) and infinite length, with constant recharge $(M)$, showing height of water table $\left(h_{0}\right)$ above draining stream.

The decline of the water table through a 90-day period without recharge was simulated by the use of MODFLOW (Harbaugh and others, 2000) for the idealized aquifer shown in figure 2. For the simulation, the aquifer was assumed to be $2,000 \mathrm{ft}$ wide ( $2 a$ ), recharge prior to the drought was $12 \mathrm{in} / \mathrm{yr}$, transmissivity of the aquifer was $100 \mathrm{ft}^{2} / \mathrm{d}$, and specific yield was 0.01 . Water-level declines in three wells tapping this idealized aquifer at various distances $(x)$ from the stream are shown in figure 3 . The magnitude of water-level decline was greatest $(13 \mathrm{ft})$ at the upland well $1,950 \mathrm{ft}$ from the stream and smallest (3.8 ft) at the near-stream well $150 \mathrm{ft}$ from the stream. The magnitude of decline appears to be a function of (1) initial height of the water table prior to the drought $\left(h_{o}\right)$ and (2) rate of watertable decline during the drought. Understanding the aquifer and basin characteristics that control the water-table height and decline rate will help identify the location of drought-sensitive aquifer settings.
Figure 3. Simulated water-level declines in wells at upland, mid-slope, and near-stream locations for the idealized aquifer shown in figure 2. 


\section{Drought Sensitive Aquifer Settings in Southeastern Pennsylvania}

\section{Height of Water Table}

The initial height of the water table for an idealized unconfined aquifer (fig. 2) of large thickness was given by Jacob (1944, eq. 2). Assuming the water table is in equilibrium with steady recharge, the water-table profile is described by

$$
h_{o}=\left(\frac{W}{T}\right)\left[a x-\frac{x^{2}}{2}\right] \text {, }
$$

where

$h_{o} \quad$ is the height of the water table above the draining stream, in feet;

$W \quad$ is the steady pre-drought recharge rate, in feet per day;

$T$ is the transmissivity, in feet squared per day;

$a$ is the distance from the stream to the ground-water divide, in feet;

and

$x \quad$ is the distance from the stream to any location on the water table, in feet.

Equation 1 indicates the height of the water table is directly related to $a, W$, and $x$ and is inversely related to $T$. The effect of well location $(x)$ within a basin can be seen in the differing initial water levels in the upland, mid-slope, and nearstream wells (fig. 3) for the drought conditions simulated for the idealized aquifer in figure 2 . In actual basins, $a$ is difficult to determine, but it can be approximated as half the reciprocal of drainage density $(D)$, where drainage density is the total length of streams divided by the basin area (Carlston, 1963) and given as

$$
a=\frac{1}{2 D}
$$

At the ground-water divide, where $x=a$, equation 1 simplifies to

$$
h_{o}=\frac{a^{2} W}{2 T} \text {. }
$$

\section{Rate of Decline}

The approximate rate of water-table decline from a steadystate condition for the ideal aquifer in figure 2 is an exponential function of transmissivity, specific yield, and distance from the stream to the ground-water divide. These properties define the hydraulic response time for the aquifer (Alley and others, 2002) and control how quickly water levels decline during drought periods. The water-table height above the stream at some time after cessation of recharge is given approximately by Jacob (1944, eq. 9) rewritten in base 10 notation as

$$
h=h_{o} 10^{\left(\frac{-t T}{0.933 a^{2} S y}\right)},
$$

where

$h \quad$ is the height of the water table at time t;

$t$ is time after cessation of recharge, in days;

and

Sy is the specific yield.

Although the variables $T, S y$, and $a$ are difficult to quantify, analysis of streamflow records can provide an index that lumps these variables together. Rorabaugh and Simons (1966) showed that the streamflow-recession index $(K)$ derived from analysis of the master recession curve equals $\left(0.933 a^{2} S y / T\right)$. In the study area of southeastern Pennsylvania, the streamflowrecession index was determined for various streams representative of basins underlain by aquifers composed primarily of either siliciclastic, crystalline, or carbonate rocks (table 3 ). The exponent ( $\left.-t T / 0.933 a^{2} S y\right)$ of equation 4 can be replaced by $(-t / K)$, so it follows that the smaller the value of $K$ in table 3 , the greater the rate of water-table decline during drought. Thus, in general, the rate of water-table decline should be greatest for siliciclastic rocks, moderate for crystalline rocks, and least for carbonate rocks.

Table 3. Streamflow-recession index $(K)$ for three streams in basins underlain by different generalized rock types in southeastern Pennsylvania.

\begin{tabular}{lccc}
\hline $\begin{array}{c}\text { U.S. Geological Survey } \\
\text { streamflow-gaging station } \\
\text { and number }\end{array}$ & $\begin{array}{c}\text { Years } \\
\text { of record }\end{array}$ & $\begin{array}{c}\text { Generalized } \\
\text { rock type } \\
\text { in basin }\end{array}$ & $\begin{array}{c}\text { Streamflow-recession } \\
\text { index }(K), \\
\text { in days }\end{array}$ \\
\hline $\begin{array}{l}\text { West Conowago Creek near Manchester } \\
(01574000)\end{array}$ & Siliciclastic & 32 \\
$\begin{array}{c}\text { French Creek near Phoenixville } \\
(01472157)\end{array}$ & 33 & Crystalline & 78 \\
$\begin{array}{l}\text { Valley Creek near Turnpike Bridge } \\
(01473169)\end{array}$ & 19 & Carbonate & 116 \\
\hline
\end{tabular}




\section{Water-Table Decline (WTD) Index}

Combining equations 3 and 4 gives an approximate expression (equations below) for the decline in water table $(\Delta h)$, in feet, at the ground-water divide of the idealized aquifer during a drought of given duration $t$

$$
\Delta h=\frac{a^{2} W}{2 T}-\left[\frac{a^{2} W}{2 T} 10^{\left(\frac{-t T}{0.933 a^{2} S y}\right)}\right]
$$

From equation 5 , it is apparent that, even for the idealized aquifer, the magnitude of ground-water decline $(\Delta h)$ after cessation of recharge is a function of at least these five variables - (1) distance from stream to divide $(a)$, (2) ground-water recharge rate $(W),(3)$ transmissivity $(T),(4)$ specific yield $(S y)$, and (5) duration of the drought $(t)$. In this report, the approximate expression for the magnitude of ground-water decline during drought for the idealized aquifer will be termed the WTD index. Because the WTD index describes the water-table decline at the divide, it can be thought of as a basin index, not affected by well location $(x)$, which should be useful for comparing the relative drought sensitivity of different aquifers.

Aquifers with a large WTD index have some combination of small $T$, small $S y$, large $a$, and large $W$. In actual aquifers with non-ideal properties, prediction of water-table declines is dependent on even more variables than for idealized aquifers. For example, in fractured-rock aquifers, $T$ may not be constant in time. This condition is especially important for aquifers with small $T$ and $S y$ that yield only marginally sufficient quantities of water to household-supply wells during periods of normal recharge. During times of drought, those marginal yields may drop at rates much greater than predicted because $T$ is decreasing as water-bearing fractures are dewatered. Practical observations regarding the fractured-rock aquifers in southeastern Pennsylvania are:

- Aquifer properties are not spatially uniform-Rocks in upland settings are more resistant to erosion and tend to be less fractured than in valleys; thus, transmissivity and specific yield values are not spatially uniform. Transmissivity commonly is smaller for aquifers beneath hills (uplands) than valleys.

- Aquifer properties are not constant with depth-The density of water-bearing fractures tends to be greatest near land surface and decreases with depth below land surface, so wells in upland settings (where the water table is deep) may be more vulnerable to the dewatering of a fracture when the water table falls during drought.

- Upland streams may not be perennial-The watertable decline during drought is greatest in upland settings most distant from streams, and the rate of decline accelerates when headwater streams become dry as drought conditions progress.
- Storage in saturated regolith is variable-The thickness of saturated regolith usually is thin to zero in upland settings but can be an important source of ground-water storage in valleys because the regolith typically has a greater capacity to store water than the underlying bedrock.

From the preceding theory and practical observations, a plausible hypothesis for the conditions creating drought-sensitive aquifer settings in southeastern Pennsylvania is that the intersection of aquifers having (1) a large WTD index and (2) upland topographic settings should provide a good first estimate of the most drought-sensitive settings in the study area. The aquifers underlying the study area were characterized using this approach.

\section{Settings Categorized by Water-Table Decline Index}

Aquifers in the study area were classified according to their WTD index (table 4). The aquifer names used in this study correspond to the nomenclature of geologic units used by the PaGS for the geologic map of Pennsylvania (Berg and others, 1980). Derivation of the WTD index from equation 5 involved estimating characteristic values of $T, S y, a$, and $W$ for each aquifer. Values of $T, S y$, and $W$ were mostly taken from published studies involving model simulation of ground-water flow (Gerhart and Lazorchick, 1984, 1988; Sloto, 1990, 2004; Vogel and Reif, 1993; Senior and Goode, 1999). Model-simulation studies were used because aquifer properties and recharge rates were derived from model calibration against observed ground-water levels and base flow. In some cases, the same aquifer was assigned appreciably different properties in different studies, so a subjective determination was made of which values would be used based on the areal extent of the aquifer and scale of the study area. Generally, values from detailed studies of small areas were assumed to be better estimates of aquifer properties than values from regional studies. The approximate distance from stream to ground-water divides $(a)$ was derived from stream-density for generalized rock types given in Gerhart and Lazorchick (1988, table 10).

\section{Settings Categorized by Topographic Position}

The topography of the study area was categorized as valley, slope, or upland by the use of a geographic information system (GIS) analysis based on the location of streams and basin divides. The valley topographic setting was defined as the area represented within a buffer of uniform width surrounding all streams classified as 3rd order or greater. Similarly, uplands were defined as the area bounded within a uniform buffer surrounding basin divides. Slopes were the areas not defined as valleys or uplands, which was most of the terrain.

Buffer widths for use in the analysis initially were assumed to be $300 \mathrm{ft}$ on each side of the stream or basin divide. Although this method of classification oversimplifies the com- 
Table 4. Categorization of aquifers in southeastern Pennsylvania by water-table decline (WTD) index.

[The distance from stream to divide was taken from Gerhart and Lazorchick (1988, p. 23). If more than two references for aquifer properties are given, first is for recharge and transmissivity values and second is for specific yield. If aquifer was anisotropic, the geometric mean of the maximum and minimum transmissivity values was used.]

References for aquifer properties: 1, Gerhart and Lazorchick (1984); 2, Vogel and Reif (1993); 3, Werkheiser (1995); 4, Gerhart and Lazorchick (1988); 5, Senior and Goode (1999); 6, Sloto (1990); 7, Sloto (2004); 8, Assumed same as plutonic; 9, Transmissivity estimated from Low and others (2002, p. 269), recharge from Low and Conger (2002), Sy assumed same as schist (Gerhart and Lazorchick, 1984); 10, Assumed same as metarhyolite and greenstone schist; 11, Assumed same as Chickies Formation

\begin{tabular}{|c|c|c|c|c|c|c|c|c|}
\hline Aquifer & $\begin{array}{l}\text { Generalized } \\
\text { rock type }\end{array}$ & $\begin{array}{c}\text { Recharge ( } M) \text {, } \\
\text { in inches per } \\
\text { year }\end{array}$ & $\begin{array}{l}\text { Distance from } \\
\text { stream to divide } \\
(a), \\
\text { in feet }\end{array}$ & $\begin{array}{c}\text { Transmissivity } \\
(T) \text {, } \\
\text { in feet squared } \\
\text { per day }\end{array}$ & $\begin{array}{c}\text { Specific yield } \\
(S y), \\
\text { dimensionless }\end{array}$ & $\begin{array}{l}\text { Water-table } \\
\text { decline } \\
\text { predicted from } \\
\text { equation } 5, \\
\text { in feet }\end{array}$ & $\begin{array}{c}\text { Water-table } \\
\text { decline (WTD) } \\
\text { index category }\end{array}$ & $\begin{array}{c}\text { References for } \\
\text { aquifer } \\
\text { properties }\end{array}$ \\
\hline $\begin{array}{l}\text { Stonehenge Formation } \\
\text { and Beekmantown } \\
\text { Group }^{1}\end{array}$ & Carbonate & 18.3 & 2,640 & 25,560 & 0.090 & 0.6 & Low & 1 \\
\hline Cockeysville Marble & Carbonate & 8.3 & 2,640 & 912 & .090 & 2.2 & Low & 2,3 \\
\hline Gettysburg Formation & Siliciclastic & 7.1 & 1,940 & 1,202 & .007 & 2.6 & Low & 4 \\
\hline Brunswick Formation & Siliciclastic & 8.2 & 1,940 & 1,050 & .007 & 3.4 & Low & 5,4 \\
\hline Millbach Formation & Carbonate & 10.7 & 2,640 & 900 & .070 & 3.5 & Low & 1 \\
\hline Ledger Formation & Carbonate & 15.1 & 2,640 & 2,100 & .080 & 3.5 & Low & 1 \\
\hline Conestoga Formation & Carbonate & 15.3 & 2,640 & 2,010 & .080 & 3.6 & Low & 1 \\
\hline $\begin{array}{l}\text { Ontelaunee and Richland } \\
\text { Formations }\end{array}$ & Carbonate & 11.3 & 2,640 & 750 & .070 & 3.8 & Low & 1 \\
\hline Zooks Corner Formation & Carbonate & 11.3 & 2,640 & 450 & .070 & 4.1 & Low & 1 \\
\hline $\begin{array}{l}\text { Buffalo Springs Forma- } \\
\text { tion }\end{array}$ & Carbonate & 11.1 & 2,640 & 330 & .070 & 4.1 & Low & 1 \\
\hline Snitz Creek Formation & Carbonate & 11.1 & 2,640 & 330 & .070 & 4.1 & Low & 1 \\
\hline Kinzers Formation & Carbonate & 11.3 & 2,640 & 300 & .070 & 4.2 & Low & 1 \\
\hline $\begin{array}{l}\text { Epler, Annville, and } \\
\text { Hershey Formations }\end{array}$ & Carbonate & 13.9 & 2,640 & 1,500 & .060 & 4.3 & Low & 1 \\
\hline Serpentinite & Crystalline & 8.4 & 1,780 & 576 & .020 & 4.7 & Low & 2,4 \\
\hline Vintage Formation & Carbonate & 13.2 & 2,640 & 300 & .070 & 4.9 & Low & 1 \\
\hline Elbrook Formation & Carbonate & 13.2 & 2,640 & 1,860 & .080 & 5.0 & Low & 6 \\
\hline Octoraro Formation & Crystalline & 6.9 & 1,780 & 150 & .020 & 7.4 & Moderate & 1 \\
\hline Stockton Formation & Siliciclastic & 15.5 & 1,940 & 900 & .005 & 7.4 & Moderate & 7 \\
\hline $\begin{array}{l}\text { Peach Bottom Slate and } \\
\text { Cardiff Conglomerate }\end{array}$ & Crystalline & 9.7 & 1,780 & 268 & .020 & 8.4 & Moderate & 4 \\
\hline Marburg Schist & Crystalline & 9.7 & 1,780 & 268 & .020 & 8.4 & Moderate & 4 \\
\hline Peters Creek Schist & Crystalline & 9.7 & 1780 & 268 & .020 & 8.4 & Moderate & 4 \\
\hline
\end{tabular}


Table 4. Categorization of aquifers in southeastern Pennsylvania by water-table decline (WTD) index.

[The distance from stream to divide was taken from Gerhart and Lazorchick (1988, p. 23). If more than two references for aquifer properties are given, first is for recharge and transmissivity values and second is for specific yield. If aquifer was anisotropic, the geometric mean of the maximum and minimum transmissivity values was used.]

References for aquifer properties: 1, Gerhart and Lazorchick (1984); 2, Vogel and Reif (1993); 3, Werkheiser (1995); 4, Gerhart and Lazorchick (1988); 5, Senior and Goode (1999); 6, Sloto (1990); 7, Sloto (2004); 8, Assumed same as plutonic; 9, Transmissivity estimated from Low and others (2002, p. 269), recharge from Low and Conger (2002), Sy assumed same as schist (Gerhart and Lazorchick, 1984); 10, Assumed same as metarhyolite and greenstone schist; 11, Assumed same as Chickies Formation

\begin{tabular}{|c|c|c|c|c|c|c|c|c|}
\hline Aquifer & $\begin{array}{l}\text { Generalized } \\
\text { rock type }\end{array}$ & $\begin{array}{c}\text { Recharge }(M) \\
\text { in inches per } \\
\text { year }\end{array}$ & $\begin{array}{l}\text { Distance from } \\
\text { stream to divide } \\
(a), \\
\text { in feet }\end{array}$ & $\begin{array}{c}\text { Transmissivity } \\
(T), \\
\text { in feet squared } \\
\text { per day }\end{array}$ & $\begin{array}{c}\text { Specific yield } \\
(S y), \\
\text { dimensionless }\end{array}$ & $\begin{array}{l}\text { Water-table } \\
\text { decline } \\
\text { predicted from } \\
\text { equation } 5, \\
\text { in feet }\end{array}$ & $\begin{array}{c}\text { Water-table } \\
\text { decline (WTD) } \\
\text { index category }\end{array}$ & $\begin{array}{c}\text { References for } \\
\text { aquifer } \\
\text { properties }\end{array}$ \\
\hline Sams Creek Metabasalt & Crystalline & 9.7 & 1,780 & 268 & 0.020 & 8.4 & Moderate & 4 \\
\hline Wissahickon Formation & Crystalline & 8.3 & 1,780 & 162 & .020 & 8.7 & Moderate & 2,4 \\
\hline Setters Quartzite & Crystalline & 8.3 & 1,780 & 144 & .020 & 9.0 & Moderate & 2,4 \\
\hline $\begin{array}{l}\text { Hammer Creek Forma- } \\
\text { tion }\end{array}$ & Siliciclastic & 15.5 & 1,940 & 700 & .005 & 9.5 & Moderate & 7 \\
\hline Plutonic Rocks ${ }^{2}$ & Crystalline & 8.3 & 1,780 & 35 & .020 & 11.0 & High & 2,4 \\
\hline Granitic Rocks & Crystalline & 8.3 & 1,780 & 35 & .020 & 11.0 & High & 8 \\
\hline New Oxford Formation & Siliciclastic & 8.4 & 1,940 & 223 & .012 & 11.4 & High & 1 \\
\hline Cocalico Formation & Siliciclastic & 11.6 & 2,080 & 300 & .015 & 12.9 & High & 1 \\
\hline Lockatong Formation & Siliciclastic & 8.2 & 1,940 & 217 & .007 & 14.1 & High & 5,4 \\
\hline Triassic Conglomerate $^{3}$ & Siliciclastic & 4.2 & 1,940 & 39 & .007 & 14.2 & High & 4 \\
\hline $\begin{array}{l}\text { Metarhyolite and Green- } \\
\text { stone Schist }\end{array}$ & Crystalline & 14.8 & 1,780 & 150 & .020 & 15.8 & High & 9 \\
\hline $\begin{array}{l}\text { Weverton and Loudon } \\
\text { Formations }\end{array}$ & Crystalline & 14.8 & 1,780 & 150 & .020 & 15.8 & High & 10 \\
\hline Gneissic Rocks ${ }^{4}$ & Crystalline & 15.5 & 1,780 & 170 & .010 & 24.3 & High & 7 \\
\hline $\begin{array}{l}\text { Antietam and Harpers } \\
\text { Formation }\end{array}$ & Crystalline & 15.5 & 1,780 & 90 & .010 & 31.5 & High & 11 \\
\hline Chickies Formation & Crystalline & 15.5 & 1,780 & 90 & .010 & 31.5 & High & 7 \\
\hline Hardyston Formation & Crystalline & 15.5 & 1,780 & 90 & .010 & 31.5 & High & 11 \\
\hline Metabasalt & Crystalline & 14.8 & 1,780 & 150 & .001 & 35.7 & High & 10 \\
\hline Diabase & Crystalline & 15.5 & 1,940 & 135 & .001 & 49.5 & High & 7 \\
\hline
\end{tabular}

${ }^{1}$ Properties of Beekmantown Group assumed same as Stonehenge Formation.

${ }^{2}$ Plutonic rocks include quartz monzonite, granodiorite, anorthosite, gabbro and gabbroic gneiss, metadiabase, metagabbro, and pegmatite.

${ }^{3}$ Triassic conglomerate includes conglomerate, limestone conglomerate, and fanglomerates.

${ }^{4}$ Gneissic rocks include granite gneiss, granodiorite gneiss, quartz monzonite gneiss, hornblende- and pyroxene-bearing felsic gneisses, graphitic gneiss, hornblende gneiss, hornblende- and pyroxene-bearing mafic gneisses, and gabbroic gneiss. 
plexities inherent in the actual terrain, the method provided a straightforward and consistent approach for categorizing the topography that was considered adequate for testing the hypothesis regarding the drought sensitivity of differing topographic positions.

\section{Documenting Drought-Affected Wells}

Information about the status of individual and public ground-water supplies during recent droughts was surveyed from various sources to determine the location and construction characteristics of wells that went dry or became unusable in southeastern Pennsylvania. For this study, any well that went dry or was replaced or deepened as a direct result of drought is termed "drought-affected." Information on drought-affected wells was solicited by (1) a well-owner survey of individual private well owners and (2) surveys of water purveyors, drillers, and government agencies such as the Pennsylvania Department of Environmental Protection (PaDEP), PaGS, county agricultural extension offices, and county health departments. The surveys were able to identify 2,016 wells affected by recent droughts (1998-2002 time period). The locations of the drought-affected wells identified by the surveys are shown in figure 4 . The distribution of drought-affected wells shown in figure 4 is an indication of where data concerning droughtaffected wells were available and should not be interpreted as illustrating drought-sensitive settings throughout southeastern Pennsylvania. Because of the uneven distribution of available data for drought-affected areas across the entire study area, much of this report focuses on data from Chester and Montgomery Counties. These counties have well-construction regulations and data considered representative of the occurrence and distribution of problem areas in those counties. Location data were used from 1,182 drought-affected wells (December 1998 through September 1999, and November 2001 through November 2002) in Chester and Montgomery Counties to determine drought-sensitive settings.

The construction characteristics of drought-affected wells were sought to determine if they were mostly old, shallow, dug wells or if deeper drilled wells of modern construction also were affected. This information could help determine if the cause of well failure was the result of site-specific, well-construction issues or a systemic inadequacy of the aquifer to supply water during drought. However, with the exception of the well-owner survey, only information on the location of the well drilled to replace or deepen the drought-affected well was readily available. Construction characteristics of the replacement wells commonly were available from well-completion reports, but that information was not useful for indicating why the original well was adversely affected during the drought.

\section{Well-Owner Survey}

Individual well owners were surveyed from March to October 2003 to identify private wells affected by the drought of 2002. The survey was published in local newspapers and also posted on the USGS Pennsylvania Water Science Center Web pages (http://water.pa.usgs.gov). Because the survey was conducted only a few months after drought-emergency status had been lifted in southeastern Pennsylvania, a significant public participation to the survey was anticipated. Contrary to expectations, public participation was small—only 35 well owners in the study area, mostly from York County, responded to the survey. The owners provided information on type of well (drilled or dug), well depth, construction date, topographic setting (upland, slope, valley), and whether or not the well had gone dry (table 5). The locations of the drought-affected wells identified by the well-owner survey are shown in figure 4 .

Results from the well-owner survey indicated most drought-affected wells were drilled (not dug) within the past 40 years, were deeper than $100 \mathrm{ft}$, and were on upland or slope settings. About 64 percent of drought-affected wells were over $100 \mathrm{ft}$ deep (all drilled), 24 percent were from 51 to $100 \mathrm{ft}$ deep ( 2 dug, 6 drilled), and 12 percent were from 0 to $50 \mathrm{ft}$ deep ( 2 dug, 2 drilled). Construction dates of the drought-affected wells ranged from 1854 to 1998; the median construction date was 1974. About 57 percent of drought-affected wells were reported to be in upland settings, 37 percent on slopes, and 6 percent in valleys.

\section{Well-Driller and Agency Surveys}

Telephone surveys were conducted during March to October 2003 by calling local well drillers and regulatory agencies in an attempt to locate information about wells affected by recent droughts. Agencies contacted included PaDEP, PaGS, county agricultural extension offices, and county health departments. Data were difficult to obtain from local well drillers and regulatory agencies because there currently (2004) is no statewide mechanism for recording information about droughtaffected wells.

One well driller provided records showing the location of 39 drought-affected wells-37 in Adams County, 1 in Cumberland County, and 1 in York County (fig. 4). The driller's records noted if the drought-affected well was replaced or deepened and provided construction information for the replacement well or modified well—but not the original drought-affected well.

The largest source of information about drought-affected wells came from the Chester and Montgomery County Health Departments. The information was available because both counties have well-construction regulations enforced through their respective health departments (Chester County Health Department, 2001; Montgomery County Health Department, 1997). As with the driller records, the information was for wells that replaced or deepened a well that went dry or became unusable during the drought; thus, the location of drought-affected 


\section{EXPLANATION}

\section{COUNTY}

\section{DRY WELLS IDENTIFIED FROM:}

- Well-owner survey

WELL-DRILLER AND AGENCY SURVEYS

- Adams County well driller

- Chester County Health Department

- Montgomery County Health Department

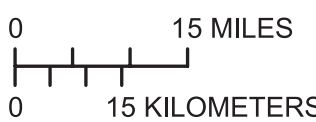

$\left.\right|_{0}$

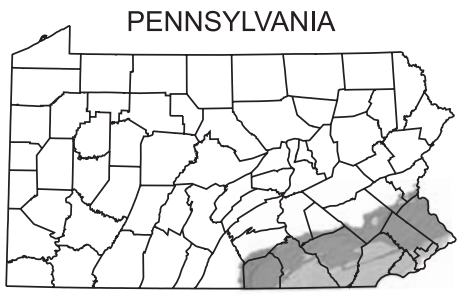

STUDY AREA
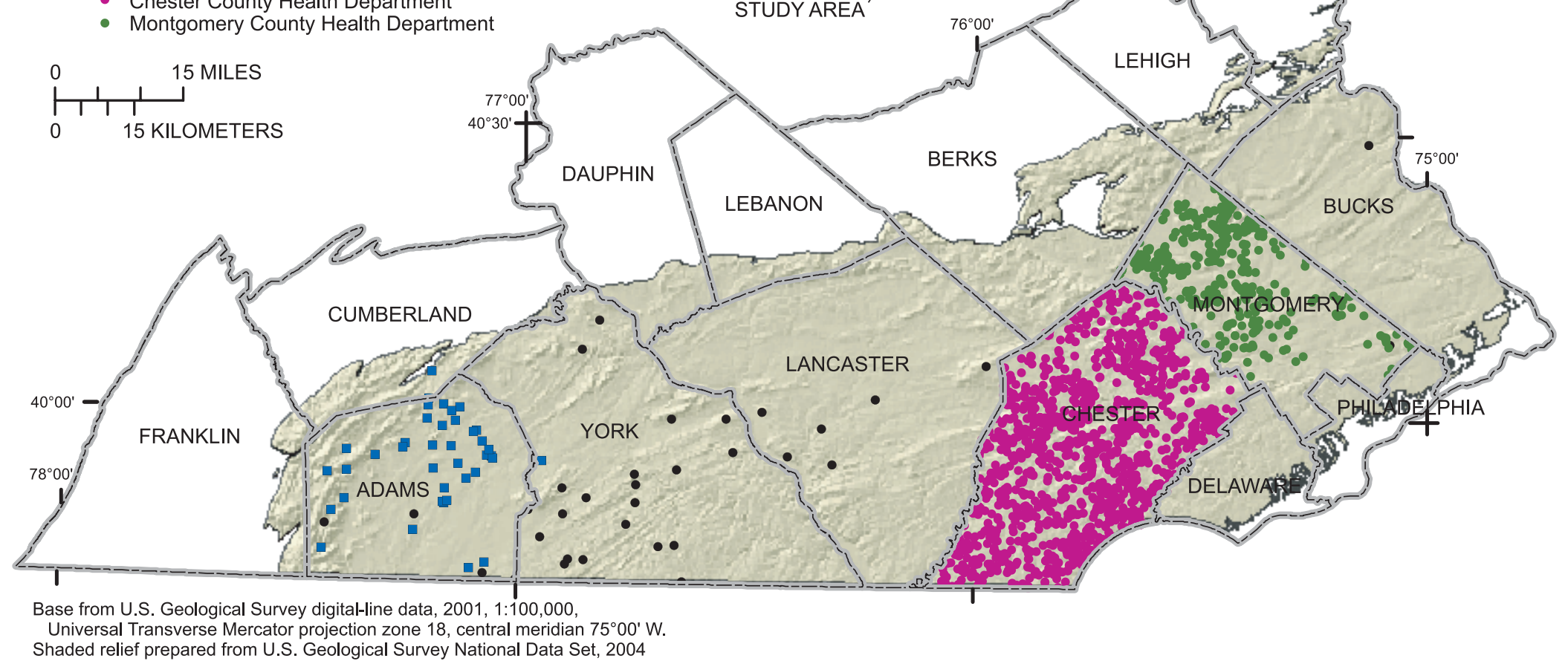

Shaded relief prepared from U.S. Geological Survey Nation meridlan 75004

Figure 4. Location of drought-affected wells in southeastern Pennsylvania during 1998-2002 as determined from results of well-owner, well-driller, and agency surveys. 
Table 5. Results from the 35 responses to the well-owner survey showing characteristics of domesticsupply wells in southeastern Pennsylvania affected by drought in 2002.

[--, unknown]

\begin{tabular}{|c|c|c|c|c|c|}
\hline Well Identifier & County & $\begin{array}{l}\text { Well depth } \\
\text { (feet) }\end{array}$ & $\begin{array}{c}\text { Well } \\
\text { construction }\end{array}$ & $\begin{array}{l}\text { Topographic } \\
\text { setting }\end{array}$ & $\begin{array}{c}\text { Year well } \\
\text { constructed }\end{array}$ \\
\hline 394849077252901 & Adams & Over 100 & drilled & upland & 1980 \\
\hline 394950077133901 & Adams & Over 100 & drilled & upland & 1994 \\
\hline 394401077043101 & Adams & $51-100$ & drilled & upland & 1960 \\
\hline 394330077000801 & Adams & Over 100 & drilled & slope & 1979 \\
\hline 402838075074501 & Bucks & Over 100 & drilled & upland & 1986 \\
\hline 400029075455801 & Chester & Over 100 & drilled & slope & 1976 \\
\hline 395805075475301 & Chester & Over 100 & drilled & slope & 1970 \\
\hline 400054076275801 & Lancaster & -- & -- & upland & 1970 \\
\hline 400554075582101 & Lancaster & Over 100 & drilled & upland & 1983 \\
\hline 400220076130101 & Lancaster & $0-50$ & dug & valley & 1929 \\
\hline 395624076243101 & Lancaster & $51-100$ & dug & upland & -- \\
\hline 395917076200601 & Lancaster & Over 100 & drilled & slope & 1963 \\
\hline 395539076183901 & Lancaster & $0-50$ & dug & upland & 1854 \\
\hline 400818075045101 & Montgomery & $0-50$ & drilled & valley & -- \\
\hline 395455076390701 & York & Over 100 & drilled & upland & 1996 \\
\hline 395320076442901 & York & Over 100 & drilled & slope & 1960 \\
\hline 400008076324501 & York & Over 100 & drilled & upland & 1998 \\
\hline 395249076541501 & York & Over 100 & drilled & valley & 1985 \\
\hline 394508076534301 & York & Over 100 & drilled & upland & 1974 \\
\hline 394536076531601 & York & Over 100 & drilled & upland & 1976 \\
\hline 394714076391501 & York & -- & -- & upland & -- \\
\hline 394916076454001 & York & Over 100 & drilled & slope & -- \\
\hline 401000076494101 & York & $51-100$ & drilled & upland & 1955 \\
\hline 394331076381401 & York & Over 100 & drilled & upland & 1978 \\
\hline 395012076540201 & York & Over 100 & drilled & upland & 1969 \\
\hline 394703076412501 & York & Over 100 & drilled & slope & 1976 \\
\hline 395422076444101 & York & $51-100$ & drilled & upland & 1973 \\
\hline 400543076431901 & York & Over 100 & drilled & upland & -- \\
\hline 400700076515501 & York & $51-100$ & dug & slope & 1960 \\
\hline 395153076510001 & York & Over 100 & drilled & upland & 1988 \\
\hline 395647076314501 & York & $51-100$ & drilled & upland & 1940 \\
\hline 395035076583801 & York & $51-100$ & drilled & slope & -- \\
\hline 395129076443401 & York & Over 100 & drilled & slope & 1991 \\
\hline 394750076570001 & York & $51-100$ & drilled & slope & 1959 \\
\hline 394536076511701 & York & $0-50$ & drilled & slope & 1967 \\
\hline
\end{tabular}


wells could be inferred from the health-department data but not the construction characteristics.

Information was obtained on 1,443 wells in Chester County and 499 wells in Montgomery County that were affected from 1998 through 2002. The number of droughtaffected wells reported each month is compared to the cumulative departure from normal precipitation (1960-89) for each county in figure 5. The factors causing more wells to be reported in Chester County than in Montgomery County is not known, but the magnitude of the precipitation deficit (especially during 2001- 2002) may have been greater in Chester County than Montgomery County (fig. 5).

\section{Comparing Hypothesized Drought-Sensitive Settings to Location of Drought-Affected Wells}

The hypothesized drought-sensitive settings were compared to the documented location of drought-affected wells to test the hypothesis that the intersection of aquifers with large WTD index with upland topographic positions should provide a good estimate of drought-sensitive settings in the study area. The analysis could not be conducted for the entire study area because information on drought-affected areas was only available in some areas. However, data from 1,182 drought-affected wells provided by the Chester and Montgomery County Health Departments were considered to be fairly representative of the occurrence and distribution of problem areas in those counties during the two most recent periods of declared drought emergency in southeastern Pennsylvania (December 1998 through September 1999, hereafter termed the 1999 drought, and November 2001 through November 2002, hereafter termed the 2002 drought).

A bias is present in the dataset of drought-affected wells associated with the uneven distribution of the population of wells that potentially could become affected during drought. For example, most residents in urban areas are served by pubic water supplies, so there are few wells affected during drought, and even in rural areas, the distribution of wells cannot be assumed to be uniform. Thus, the reported number of droughtaffected wells from the county health departments was used in two ways to determine if the hypothesized drought-sensitive settings differ. The number of drought-affected wells for each WTD index category (high, moderate, low) and topographic setting (valley, slope, upland) were reported on the basis of (1) wells per square mile and (2) percentage of wells from the PaGS WWI. Although the WWI does not contain the entire population of wells in the study area, the WWI should represent the relative distribution of wells among aquifers.

The spatial density of drought-affected wells in Chester and Montgomery Counties was evaluated as a preliminary analysis to illustrate potential drought-sensitive areas, strictly on the basis of the locations of wells obtained from the county health

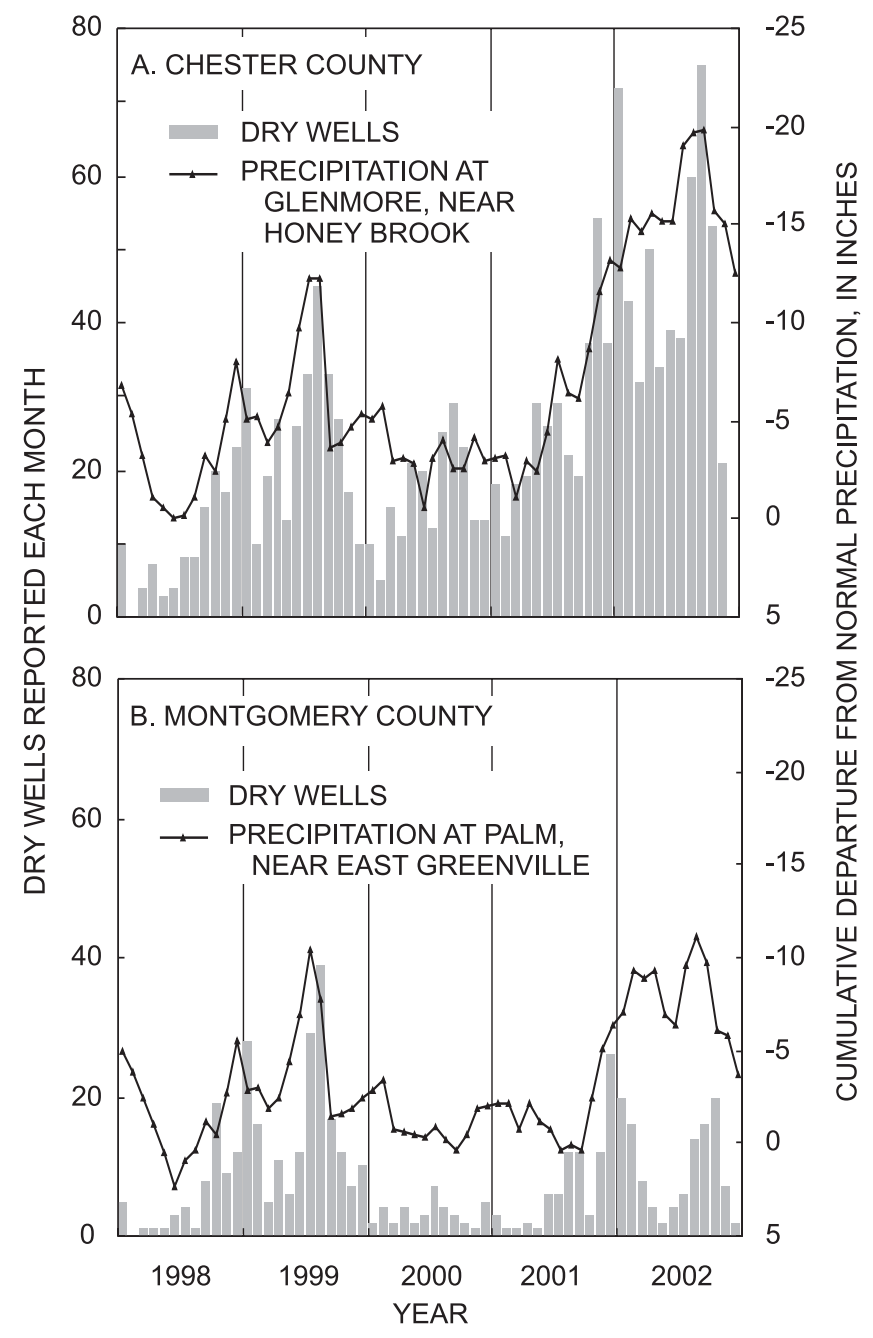

Figure 5. Drought-affected wells reported by Chester and Montgomery County Health Departments and cumulative departure from normal precipitation, 1998-2002.

departments. A continuous-density surface was created with a GIS for the drought-affected wells during recent periods of declared drought in Pennsylvania (1999 and 2002 droughts). In Chester County, areas with a high density of drought-affected wells occurred in a widely distributed splotchy pattern (fig. 6A). The largest area of drought-affected wells was northwest of South Coatesville, which may be associated with the gneissic bedrock. In Montgomery County, the highest density of drought-affected wells was east of Green Lane and in an area north of Pottstown (fig. 6B). These areas appear to be associated with diabase bedrock and the associated hornfels (baked shales) within the Brunswick and Lockatong Formations. 


\section{A. Chester County}

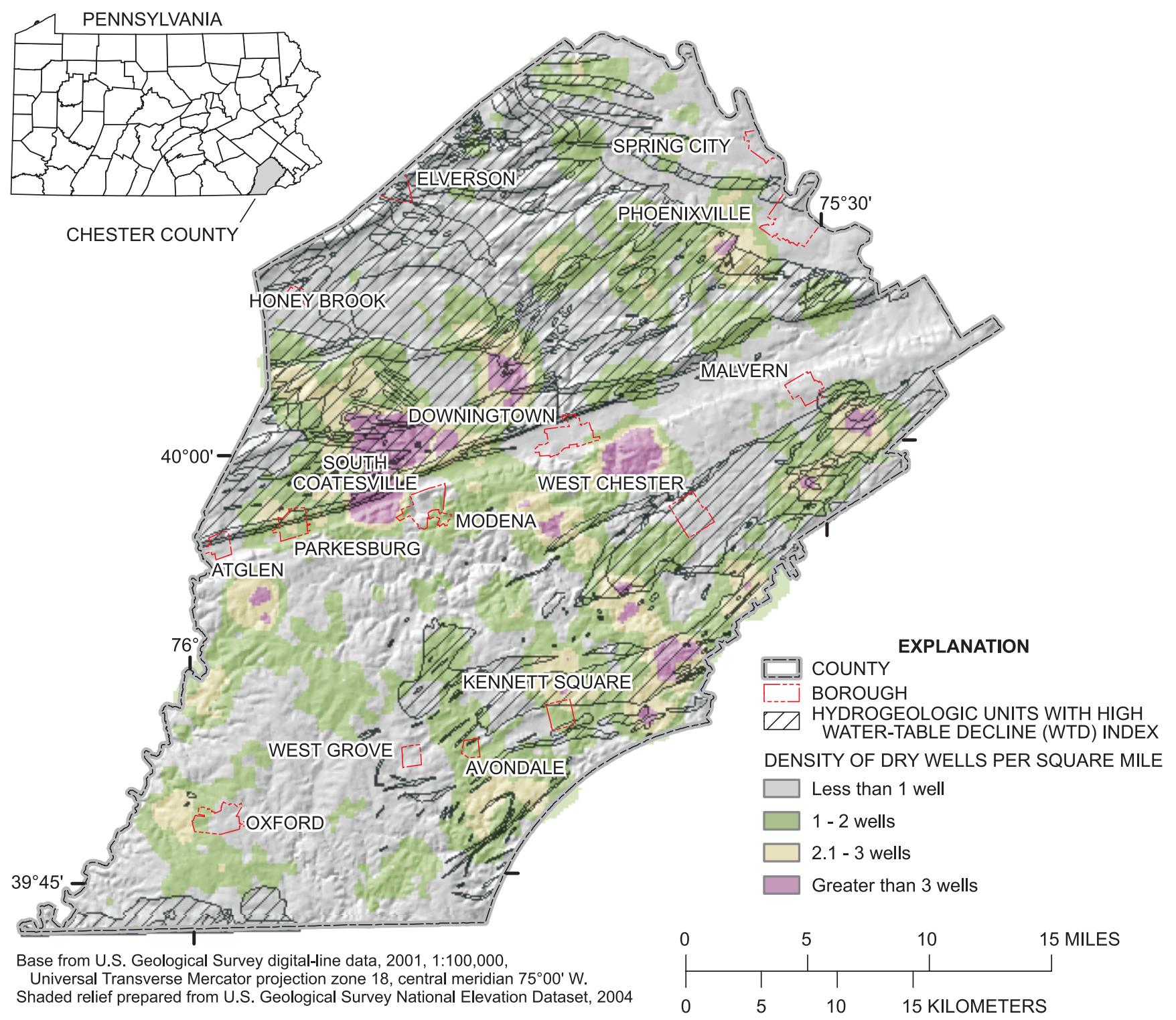

Figure 6. Density of drought-affected wells during the 1999 and 2002 droughts in (A) Chester County and (B) Montgomery County, Pennsylvania. 


\section{B. Montgomery County}

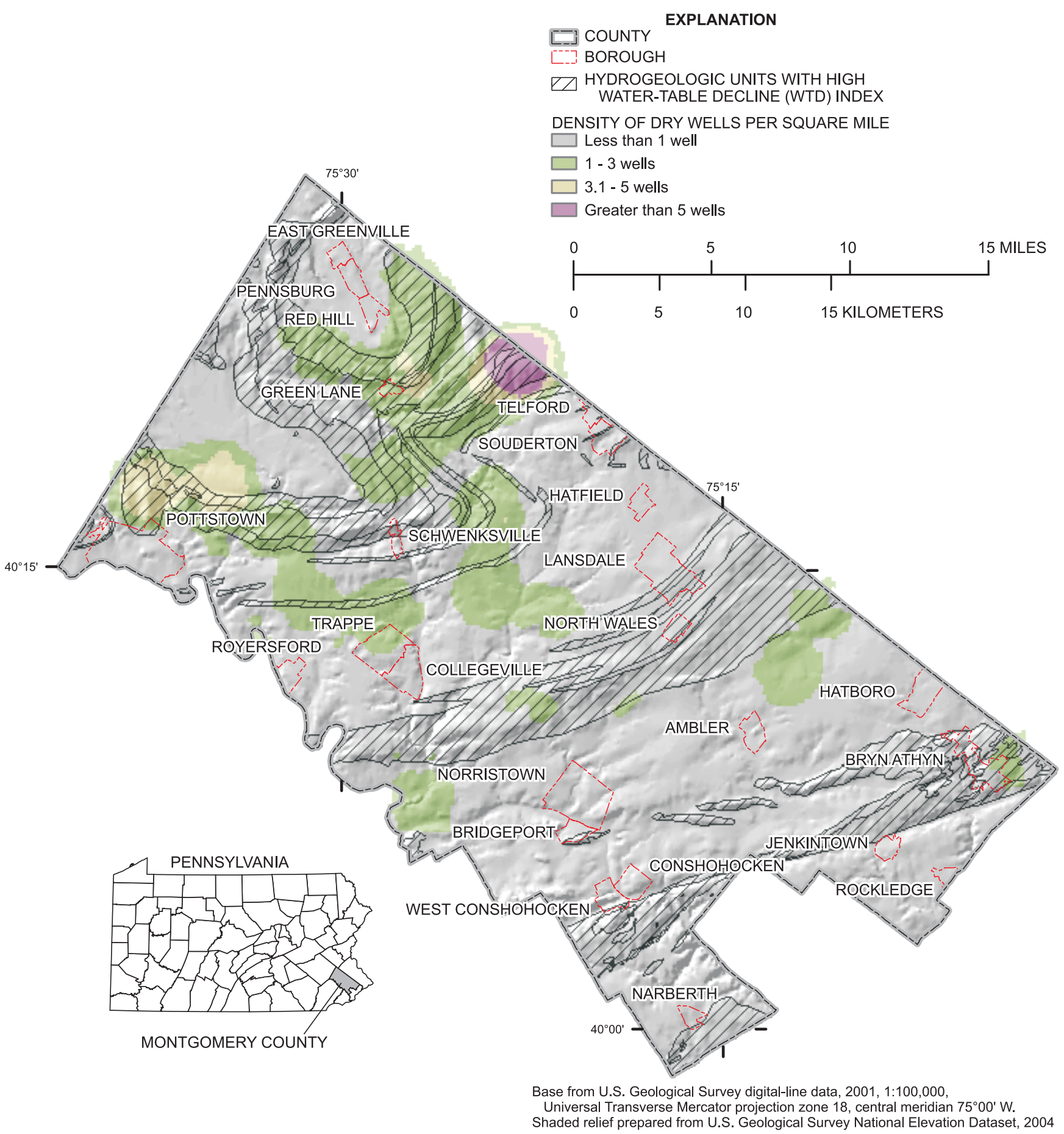

Figure 6. Density of drought-affected wells during the 1999 and 2002 droughts in (A) Chester County and (B) Montgomery County, Pennsylvania.-Continued 


\section{Drought Sensitive Aquifer Settings in Southeastern Pennsylvania}

\section{Water-Table Decline Index}

The hypothesis that drought-sensitive settings were related to the location of aquifers with high WTD index was tested by comparing areas of Chester and Montgomery Counties underlain by aquifers of low, moderate, and high WTD index to the locations of drought-affected wells obtained from the county health departments. The number of drought-affected wells per $100 \mathrm{mi}^{2}$ from the 1999 and 2002 droughts was determined for each aquifer having an area greater than $5 \mathrm{mi}^{2}$ in Chester and Montgomery Counties (table 6). The highest frequency of drought-affected wells (173 wells $/ 100 \mathrm{mi}^{2}$ ) was in the diabase and hornfels, and the lowest frequency was documented in the Elbrook Formation (15 wells/100 $\mathrm{mi}^{2}$ ).

The frequency of drought-affected wells reported during the 1999 and 2002 droughts from the Chester and Montgomery County Health Departments was compared to the WTD index of aquifers in figure 7 . The comparison showed a strong relation between WTD-index category of the aquifer and number of drought-affected wells per $100 \mathrm{mi}^{2}$ - aquifers categorized as having low WTD index had about 62 dry wells per $100 \mathrm{mi}^{2}$ compared to about 125 wells per $100 \mathrm{mi}^{2}$ for the high WTDindex category. When drought-affected wells are viewed on the basis of percentage of WWI wells in each WTD-index category (using WWI wells as a surrogate for the total number of wells in Chester and Montgomery Counties), there is a clear difference between the percentage of dry wells for aquifers categorized as low WTD index (4 percent) and high WTD index (11 percent). However, there is little difference between the moderate and high WTD index categories.

For some of the aquifers, the number of drought-affected wells reported in table 6 was greater or less than expected for its assigned WTD index category. For example, there were more drought-affected wells reported in the Cockeysville Marble than expected for an aquifer with low WTD index, more in the Setters Quartzite and Peters Creek Schist than expected for aquifers with moderate WTD, and fewer in the Lockatong Formation and Plutonic rocks than expected for aquifers with high WTD index. Some of the discrepancy probably is caused by the topographic setting of the drought-affected wells, which is not accounted for in the WTD index. However, in some cases, the

Table 6. Dry wells in each aquifer in Chester and Montgomery Counties, Pennsylvania, expressed per 100 square miles and as percentage of Water Well Inventory (WWI) wells.

[Aquifer with an area of 5 square miles or less in the study area are not shown. Water-table decline index categories are described in table 4.]

\begin{tabular}{|c|c|c|c|c|c|c|}
\hline \multirow[b]{2}{*}{ Aquifer } & \multirow[b]{2}{*}{$\begin{array}{l}\text { Water-table } \\
\text { decline } \\
\text { index }\end{array}$} & \multirow{2}{*}{$\begin{array}{c}\text { Area of } \\
\text { aquifer } \\
\text { (square } \\
\text { miles) }\end{array}$} & \multirow[b]{2}{*}{$\begin{array}{l}\text { WWI } \\
\text { wells }\end{array}$} & \multicolumn{3}{|c|}{ Drought-affected wells } \\
\hline & & & & $\begin{array}{l}\text { Number } \\
\text { reported }^{1}\end{array}$ & $\begin{array}{l}\text { Per } 100 \\
\text { square } \\
\text { miles }\end{array}$ & $\begin{array}{c}\text { Percentage } \\
\text { of WWI } \\
\text { wells }\end{array}$ \\
\hline Elbrook Formation & Low & 13.7 & 30 & 2 & 14.6 & 6.7 \\
\hline Ledger Formation & Low & 22.8 & 159 & 6 & 26.3 & 3.8 \\
\hline Conestoga Formation & Low & 24.7 & 123 & 13 & 52.7 & 10.6 \\
\hline Brunswick Formation & Low & 196.9 & 3,797 & 135 & 68.6 & 3.6 \\
\hline Cockeysville Marble & Low & 10.2 & 41 & 11 & 107.7 & 26.8 \\
\hline Stockton Formation & Moderate & 106.7 & 877 & 52 & 48.7 & 5.9 \\
\hline Hammer Creek Conglomerate & Moderate & 8.8 & 91 & 6 & 68.2 & 6.6 \\
\hline Wissahickon Formation & Moderate & 215.0 & 1,728 & 172 & 80.0 & 10.0 \\
\hline Octoraro Formation & Moderate & 51.3 & 464 & 51 & 99.4 & 11.0 \\
\hline Setters Quartzite & Moderate & 11.8 & 65 & 14 & 118.5 & 21.5 \\
\hline Peters Creek Schist & Moderate & 68.4 & 594 & 88 & 128.7 & 14.8 \\
\hline Lockatong Formation & High & 58.8 & 570 & 31 & 52.7 & 5.4 \\
\hline Plutonic Rocks & High & 31.1 & 266 & 23 & 74.0 & 8.6 \\
\hline Gneissic Rocks & High & 276.6 & 2,565 & 346 & 125.1 & 13.5 \\
\hline Antietam and Harpers & High & 9.0 & 75 & 12 & 133.4 & 16.0 \\
\hline Chickies Formation & High & 34.7 & 427 & 54 & 155.6 & 12.6 \\
\hline Diabase + Hornfels & High & 94.0 & 1,858 & 163 & 173.4 & 8.8 \\
\hline
\end{tabular}

\footnotetext{
${ }^{1}$ The number of wells reported by the Chester and Montgomery Health Departments during the 1999 and 2002 droughts.
} 


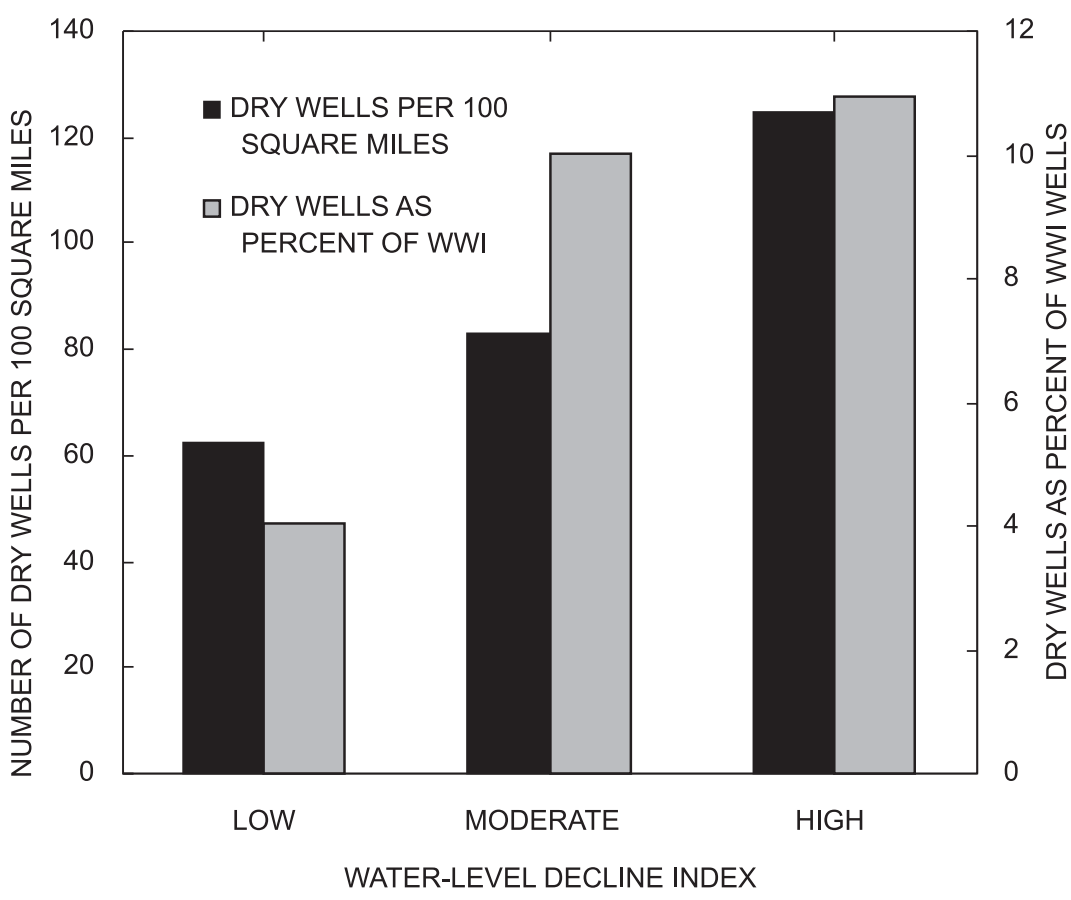

Figure 7. Relation between water-table decline index (low, moderate, high) and incidence of drought-affected wells reported by Chester and Montgomery County Health Departments, southeastern Pennsylvania, during the 1999 and 2002 droughts and as a percentage of Water Well Inventory (WWI) wells.
WTD index may not be representative of the aquifer or the number of drought-affected wells might have been affected by factors such as nearby ground-water withdrawals or land-use changes that were not considered in this analysis.

\section{Topographic Position}

The hypothesis that drought-sensitive settings are related to the topographic position was tested by comparing valley, slope, and upland settings in Chester and Montgomery Counties to the locations of drought-affected wells obtained from the well owner, driller, and agency surveys. The settings initially were delineated by classifying valleys with a 300-ft buffer around streams and uplands with a 300-ft buffer around basin divides. All other areas were classified as slopes.

To determine if this arbitrary topographic classification could be improved, the width of the stream buffer identifying the valley position was varied by the use of a GIS analysis, and the number of drought-affected wells per $100 \mathrm{mi}^{2}$ was recorded. Streams were buffered at $100 \mathrm{ft}$ increments up to 2,000 ft and at $500 \mathrm{ft}$ increments from 2,000 to 5,000 ft. The number of dry wells increased noticeably between the 300 and $400 \mathrm{ft}$ streambuffer widths. This increase indicates that wells are more vulnerable to drought if located more than $300 \mathrm{ft}$ from a stream. This analysis indicates the use of the arbitrarily proposed $300-\mathrm{ft}$ buffer surrounding streams is probably optimal for defining the valley setting (in this simple topographic classification scheme) for purposes of identifying drought-sensitive settings.

The comparison of valley, slope, and upland topographic positions in Chester and Montgomery Counties to the locations of drought-affected wells reported by the county health departments during the 1999 and 2002 droughts showed the number of drought-affected wells per $100 \mathrm{mi}^{2}$ appears to be strongly related to topographic position (fig. 8). Upland settings have about 154 drought-affected wells per $100 \mathrm{mi}^{2}$ compared to about 57 wells per $100 \mathrm{mi}^{2}$ in valleys. The same strong relation also holds if drought-affected wells are expressed as a percentage of wells in the WWI database (fig. 8).

\section{Combined Factors}

Nine possible drought-sensitive settings were identified for southeastern Pennsylvania by combining the three categories of drought-sensitive aquifer (high, moderate, and low) with the three categories of topographic position (valley, slope, and upland). The hypothesis that the intersection of aquifers having high WTD index with upland topographic positions provides a good estimate of the most drought-sensitive settings in the study area was tested by comparing the nine settings to the locations of drought-affected wells during the 1999 and 2002 droughts obtained from the Chester and Montgomery County Health Departments. The settings were compared on the basis of (1) wells per $100 \mathrm{mi}^{2}$ and (2) percent of wells from WWI in table 7 .

The results shown in table 7 differ depending on the basis of the comparison-wells per square mile or percentage of wells from the WWI. In each table, the nine settings were divided equally into categories of low, moderate, or high drought sensitivity. The three most highly sensitive settings, on the basis of either criteria, were (1) uplands in aquifers with high WTD index, (2) slopes in aquifers with high WTD, and (3) uplands in aquifers with moderate WTD index (cells with red shading in table 7). The two least-sensitive settings, as determined from either criterion, were valleys and slopes in aquifers 


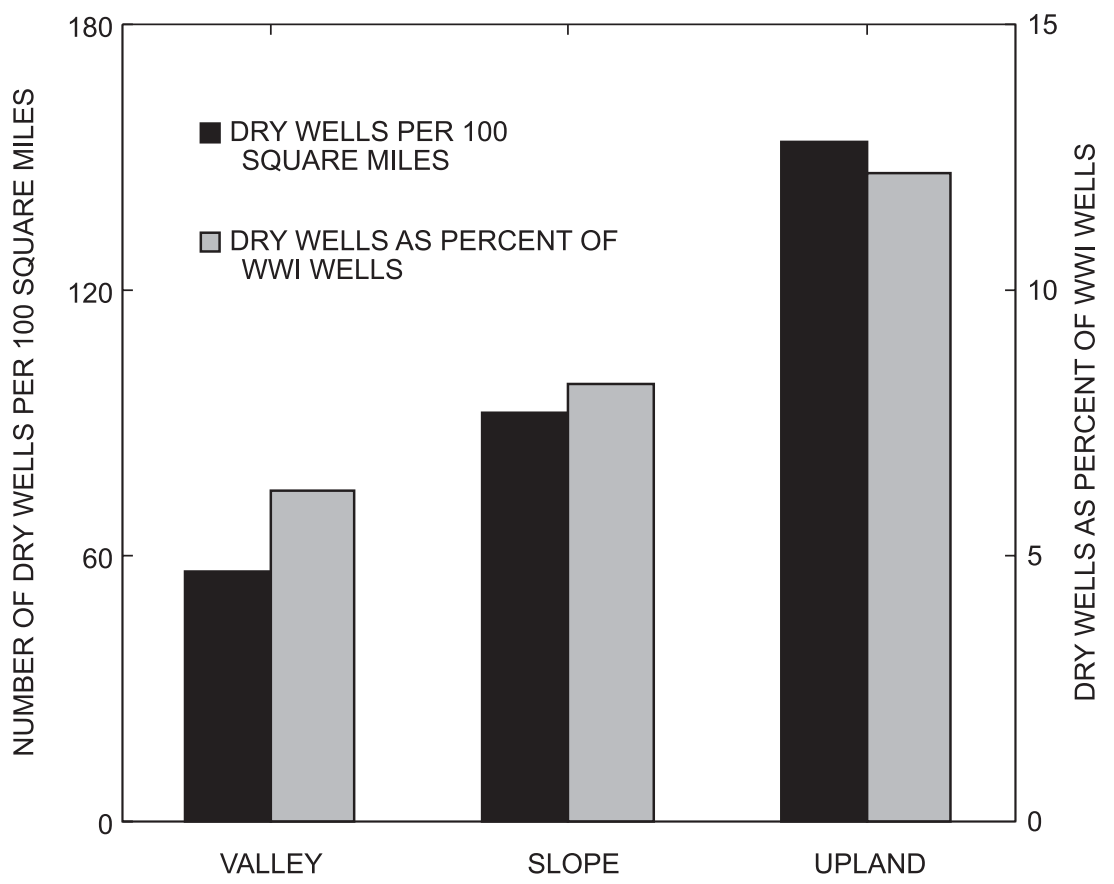

Figure 8. Relation between topographic position (valley, slope, upland) and incidence of drought-affected wells reported by Chester and Montgomery County Health Departments, southeastern Pennsylvania, during the 1999 and 2002 droughts and as a percentage of Water Well Inventory (WWI) wells.

Table 7. Comparison of drought-affected wells (1999 and 2002 droughts) in Chester and Montgomery Counties, Pennsylvania, in nine settings defined as the intersection of water-table decline (WTD) index and topographic position.

\begin{tabular}{|c|c|c|c|}
\hline \multirow{2}{*}{ Topographic position } & \multicolumn{3}{|c|}{ WTD INDEX } \\
\hline & Low & Moderate & High \\
\hline \multicolumn{4}{|c|}{ Basis of Comparison-Drought-affected wells per 100 square mile } \\
\hline Valley & 44 & 54 & 69 \\
\hline Slope & 63 & 81 & 118 \\
\hline Upland & 74 & 141 & 195 \\
\hline \multicolumn{4}{|c|}{$\begin{array}{l}\text { Basis of Comparison-Drought affected wells as a percentage of } \\
\text { Water Well Inventory wells. }\end{array}$} \\
\hline Valley & 2.9 & 9.9 & 8.0 \\
\hline Slope & 4.2 & 9.8 & 10.3 \\
\hline Upland & 4.5 & 13.4 & 15.3 \\
\hline
\end{tabular}

of low WTD index (cells with green shading in table 7). Settings of moderate drought sensitivity could be found in aquifers of any WTD-index category or topographic position depending on the basis of comparison (drought-affected wells per square mile or percentage of wells in WWI).

The hypothesis that the WTD index and topographic position can be used to estimate the relative drought sensitivity of settings in southeastern Pennsylvania seems to be supported by data on drought-affected wells in Montgomery and Chester Counties from table 7 . The relative sensitivity of the settings derived from table 7 is generalized for the entire study area in figure 9. It is difficult to draw conclusions more specific than those presented here for three major reasons listed below:

1. The WTD index was developed for an idealized aquifer that is a greatly simplified representation of the fractured-rock aquifers in southeastern Pennsylvania. It requires estimates of four physical parameters-(1) distance from stream to divide, (2) ground-water recharge rate, (3) transmissivity, and (4) specific yield that are not well known; thus, there is large uncertainty in the determination of WTD index.

2. Data on drought-affected wells were not available for the 


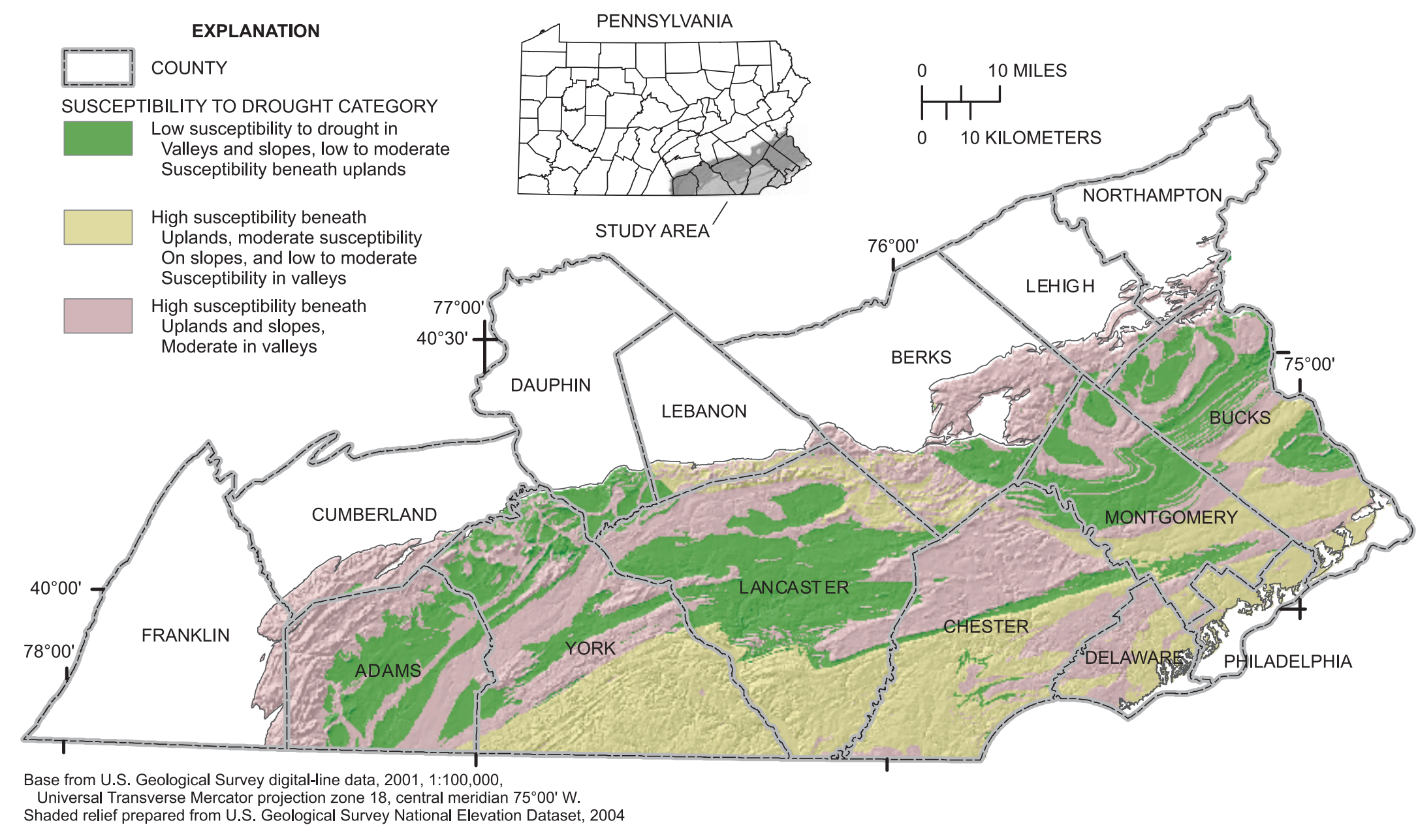

Figure 9. Drought-sensitive settings in southeastern Pennsylvania determined by water-table decline index of aquifers and topographic position. 
entire study area. Thus, the hypothesized drought sensitivity of many aquifers in southeastern Pennsylvania could not be compared to the occurrence of droughtaffected wells during recent droughts.

3. It is difficult to know how to interpret the information on drought-affected wells provided by Montgomery and Chester County Health Departments. In addition to WTD index and topographic position, factors that could affect the number of reported drought-affected wells are (a) uneven distribution of the population of wells available to go dry during drought, (b) unequal distribution of shallow wells, which are more likely to go dry than deep wells, (c) spatial differences in precipitation deficit during the drought, (d) possible differences in the degree of consistency among drillers in reporting drought-affected wells, and (e) factors such as nearby ground-water withdrawals or land-use changes that were not part of this analysis.

\section{Summary and Conclusions}

All or parts of southeastern Pennsylvania have been in drought-warning or drought-emergency status during 6 of the past 10 years from 1994 through 2004. As a result, low domestic ground-water levels have caused hundreds of domestic-supply wells to go dry or become unusable. Therefore, a study was conducted by the U.S. Geological Survey, in cooperation with the Pennsylvania Department of Conservation and Natural Resources, Bureau of Topographic and Geologic Survey, to determine drought-sensitive aquifer settings in southeastern Pennsylvania where ground-water shortages may occur during drought.

The study area is approximately $5,100 \mathrm{mi}^{2}$ and spans all or parts of Adams, Berks, Chester, Cumberland, Dauphin, Delaware, Franklin, Lancaster, Lebanon, Lehigh, Montgomery, Northampton, and York counties. Geology varies from igneous and metamorphic rocks of Precambrian age to sedimentary rocks of Triassic age. Aquifer characteristics within the study are diverse but the fractured-rock aquifers can be categorized according to crystalline, siliciclastic, and carbonate-rock types. The aquifer names used in this study correspond to the nomenclature of geologic units used by the Pennsylvania Geologic Survey. Ground water in these aquifers moves primarily within fracture space in the rock, although in some valley settings the saturated regolith can store and transmit water. The frequency of water-bearing fractures tends to diminish with depth. Therefore, ground-water flow paths are local and shallow-generally less than $400 \mathrm{ft}$ deep.

Drought-sensitive aquifer settings were first defined conceptually using information from previous investigations and knowledge of the hydrogeology and topography of the study area. It was hypothesized that wells will be most affected by drought in aquifer settings having the factors of high WTD index and upland topographic positions. WTD index was devel- oped from equations of Jacob to estimate the maximum decline of the water table at a basin divide for a hypothetical aquifer with idealized geometry. The WTD index shows that the magnitude of ground-water decline after cessation of recharge is a function of (1) distance from stream to ground-water divide, (2) ground-water recharge rate, (3) transmissivity, (4) specific yield, and (5) duration of the drought. Aquifers in the study area were divided into categories of low, moderate, and high WTD index, and the topography was classified into valley, slope, and upland positions.

The hypothesized factors affecting drought were compared to locations of drought-affected wells to confirm or refute the hypothesis that these factors are problematic during drought. The information about drought-affected wells was obtained from surveys of well owners, drillers, and public agencies. Data were obtained from 2,016 wells in southeastern Pennsylvania that went dry or were problematic during the drought in 1998-2002. With the exception of the owner-derived information from 35 wells from a well-owner survey, well-construction data were only obtained for the replacement or modified wells and not the original wells that went dry. The depths of drought-affected wells generally were not available, which made it impossible to determine if the drought-related well failure was caused by an appreciable deficiency of the aquifers to supply water or if the well was too shallow to tap a significant portion of the saturated thickness of the aquifer.

An analysis of the drought-affected wells could not be conducted for the entire study area because information on droughtaffected areas was only obtained in some areas, but the occurrence and distribution of drought-affected wells in Chester and Montgomery Counties were considered to be fairly representative of problem areas in those two counties associated with the two declared periods of drought from December 1998 through September 1999 (termed "the 1999 drought" in this report) and November 2001 through November 2002 (termed "the 2002 drought" in this report). Thus, the locations of 1,182 droughtaffected wells from those counties during the two periods of declared drought were used to evaluate drought-sensitive aquifers and topographic positions

In general, the occurrence of drought-affected wells was found to be greater in aquifers having high or moderate WTD index in Chester and Montgomery Counties compared to aquifers with low WTD index. The occurrence of drought-affected wells also appears to be strongly related to topography; upland settings have about 154 drought-affected wells per $100 \mathrm{mi}^{2}$ compared to about 57 wells per $100 \mathrm{mi}^{2}$ in valleys.

The three most drought-sensitive settings were (1) uplands in aquifers with high WTD index, (2) slopes in aquifers with high WTD index, and (3) uplands in aquifers with moderate WTD. The two least sensitive settings were valleys and slopes in aquifers of low WTD index. 


\section{Acknowledgments}

This project was developed initially by William Werkheiser of USGS and Samuel Berkheiser of PaGS. Datasets on drought-affected wells were provided by Kyle Schmeck of the Montgomery County Health Department and Benjamin Aller of the Chester County Health Department. Review of the report was provided by Gary Fleeger and Thomas McElroy of T\&GS, and Lisa Senior, Curtis Schreffler, and Kim Otto of USGS.

\section{References Cited}

Alley, W.H., Healy, R.W., LaBaugh, J.W., and Reilly, T.E., 2002, Flow and storage in groundwater systems: Science, v. 296, p. 1985-1990.

Berg, T.M., Edmunds, W.E., Geyer, A.R., Glover, A.D., Hoskins, D.M., MacLachlan, D.B., Root, S.I., Sevon, W.D., and Socolow, A.A., comps., 1980, Geologic map of Pennsylvania: Pennsylvania Geological Survey, 4th ser., map 1, scale 1:250,000, 3 sheets.

Carlston, C.W., 1963, Drainage density and streamflow: U.S. Geological Survey Professional Paper 422-C, 8 p.

Chester County Health Department, 2001, Rules and regulations-Water well construction, monitoring wells, and individual semi-public water supplies: chap. 500, sec. 501, 24 p.

Fleeger, G.M., 1999, The geology of Pennsylvania's groundwater: Pennsylvania Geological Survey, $4^{\text {th }}$ series, Educational Series 3, 34 p.

Gerhart, J. M., and Lazorchick, G. J., 1984, Evaluation of the ground-water resources of parts of Lancaster and Berks Counties, Pennsylvania: U.S. Geological Survey WaterResources Investigations Report 84-4327, 135 p.

Gerhart, J. M., and Lazorchick, G. J., 1988, Evaluation of the ground-water resources of the Lower Susquehanna River Basin, Pennsylvania and Maryland: U.S. Geological Survey Water-Supply Paper 2284, 128 p.

Harbaugh, A.W., Banta, E.R., Hill, M.C., and McDonald, M.G., 2000, MODFLOW-2000, the U.S. Geological Survey modular ground-water model-User guide to modularization concepts and the ground-water flow process: U.S. Geological Survey Open-File Report 00-92, 121 p.

Jacob, Charles E., 1944, Correlation of ground-water levels and precipitation on Long Island, New York; part 1, theory; part 2 correlation of data: Transactions of the American Geophysical Union, part 2, part 6 (Jan.), p. 564-573.

Low, D.J., and Conger, R.W., 2002, Ground-water availability in part of the Borough of Carroll Valley, Adams County, Pennsylvania, and the establishment of a drought-monitor well: U.S. Geological Survey Water-Resources Investigations Report 02-4273, 78 p.
Low, D.J., Hippe, D.J., and Yannacci, D., 2002, Geohydrology of southeastern Pennsylvania: U.S. Geological Survey Water-Resources Investigations Report 00-4166, 347 p.

Montgomery County Health Department, 1997, Montgomery County Public Health Code-Division of Water Quality Management individual water supply system regulations: chap. 17 , sec. 17,9 p.

Pennsylvania Department of Environmental Protection, 2004, Drought information center: accessed December, 1, 2004, at http://www.dep.state.pa.us/dep/subject/hotopics/drought/.

Rorabaugh, M.I., and Simons, W.D., 1966, Exploration of methods relating ground water to surface water, Columbia River basin-second phase: U.S. Geological Survey OpenFile Report, 62 p.

Senior, L.A., and Goode, D.J., 1999, Ground-water system, estimation of aquifer hydraulic properties, and effects of pumping on ground-water flow in Triassic sedimentary rocks in and near Lansdale, Pennsylvania: U.S. Geological Survey Water-Resources Investigations Report 99-4228, 112 p.

Sevon, W. D., 2000, Physiographic provinces of Pennsylvania (4th ed.): Pennsylvania Geological Survey, 4th ser., map 13, scale 1:2,000,000.

Sloto, R. A., 1990, Geohydrology and simulation of groundwater flow in the carbonate rocks of the Valley Creek basin, eastern Chester County, Pennsylvania: U.S. Geological Survey Water-Resources Investigations Report 89-4169, $60 \mathrm{p}$.

Sloto, R. A., 2004, Geohydrology of the French Creek Basin and simulated effects of drought and ground-water withdrawals, Chester County, Pennsylvania: U.S. Geological Survey Water-Resources Investigations Report 03-4263, 82 p.

U.S. Bureau of the Census, 1992, Census of population and housing, 1990: Washington, D.C., Summary Tape File 3 on CD-ROM [machine-readable data files].

U.S. Geological Survey, 2004, National elevation dataset: U.S. Geological Survey data available on the Web, accessed January 10, 2005, at http://ned.usgs.gov/.

Vogel, K. L., and Reif, A.G., 1993, Geohydrology and simulation of ground-water flow in the Red Creek Basin, Chester County, Pennsylvania and New Castle County

Delaware: U.S. Geological Survey Water-Resources Investigations Report 93-4055, 111 p.

Werkheiser, W.H., 1995, Geohydrology of the Hockessin area with emphasis on the Cockeysville Aquifer, in Woodruff, K.D., and Plank, M.O., eds., Geology and hydrogeology of the Cockeysville Formation Northern New Castle County, Delaware: Delaware Geological Survey Bulletin, no. 19, p. 26-48. 